\title{
Patronage, Punch-Ups, and Polite Correspondence: The Radical Background of James Woodhouse's Early Poetry
}

\author{
Adam J. Bridgen
}

\begin{abstract}
A BSTRACT In this essay, Adam Bridgen argues that the oft-condemned "sycophancy" of James Woodhouse's early poetry is a misapprehension that overlooks the emergence of his evangelical, egalitarian beliefs in the mid-1760s. Reconsidering the letters between Woodhouse and his patrons reveals not only the influential friendships he cultivated as a plebeian poet but also the class prejudices he continued to encounter and resist, often forcefully. Although he conformed to a humble self-portrayal in his 1764 and 1766 Poems, Woodhouse's subversion of praise allowed him to criticize as well as commend elite behavior; viewing benevolence as a Christian duty faithful to the more equal society that God had intended, he praised patronage, in fact, for its leveling potential. KEY wORDS: eighteenthcentury British poetry; laboring-class writing; literary patronage; epistolary correspondence and the familiar letter; epideictic rhetoric and the politics of praise
\end{abstract}

Worcestershire is certainly the land of Poets, \& there is a good collection of verses publish'd by a journeyman cobbler in that country. He is far above Stephen Duck. ${ }^{1}$

LIKE ALMOST ALL laboring-class writers in the eighteenth century, James Woodhouse (1735-1820) relied on the patronage of benefactors-without whom he would have lacked the money and connections necessary to write and publish books of

1. Elizabeth Montagu to Elizabeth Handcock, June 5, 1764, Montagu Collection, MO 6376, Huntington Library. Further references to manuscript letters from the collection will be given in the text, using the abbreviation MO. All transcriptions are my own: words added for clarification, amended punctuation, and elisions (for brevity or due to damage) are indicated by square brackets; angle brackets denote authorial deletions; authorial insertions are indicated with $\vee$; full stops added to the end of block quotations and modernized monetary symbols have not been bracketed.

Pp. 99-134. @2017 by Henry E. Huntington Library and Art Gallery. ISSN 0018-7895 | E-ISSN 1544-399x. All rights reserved. For permission to photocopy or reproduce article content, consult the University of Pennsylvania Press Rights and Permissions website, http://www.upenn.edu/pennpress/about/permissions.html. 
poetry. ${ }^{2}$ The agricultural laborer Stephen Duck (ca. 1705-1756) had set an influential precedent for poets and patrons alike, securing preferment through a timely introduction to Queen Caroline: he became poet-in-residence at Richmond Gardens and was even rumored for the laureateship. ${ }^{3}$ Like Duck, Woodhouse expressed immense gratitude toward his patrons, who included, in quick succession following his discovery in 1759, William Shenstone (1714-1763), George Lyttelton (1709-1773), and finally Elizabeth Montagu (1718-180o). Woodhouse's Poems on Sundry Occasions (1764) and Poems on Several Occasions (1766) are replete with prefatory as well as poetic tributes to his patrons and supporters, and have since been seized upon by critics as exemplars of the "humble" self-portrayal through which plebeian poets gained admission into the polite cultural sphere. Nevertheless, like other, later laboring-class writers, Woodhouse's reputation has been defined by his ultimate estrangement from his patrons, particularly Elizabeth Montagu. 4 In 1949 Katherine Hornbeak published an influential forensic account of their relationship based on a selection of their correspondence held in the Huntington Library. Hornbeak charted the mutually "rapturous" early stages of Woodhouse's patronage and subsequent employment by the Montagus, in 1767 , as land bailiff of their Newbury estate, and the tensions, evident from 1769 onward, leading up to his second (and final) dismissal in 1788.5 Once released from Montagu's service, Woodhouse brought out a new collection of poetry, briefly alluding to his mistreatment in the "Address to the Public." ${ }^{6}$ Offering no further details of his

2. On this point, see Dustin Griffin, Literary Patronage in England 1650-180o (Cambridge, 1996), 189-95. Griffin does not, however, take into account other, more popular publishing avenues, such as newspapers, periodicals, and miscellanies; the exploration of such vibrant literary subcultures might challenge the prevailing assumption that laboring-class writers "would have wasted their sweetness on the desert air if they had not been adopted by patrons" (289).

3. Stephen Duck's unusual royal patronage was variously interpreted over the course of the eighteenth century. See Susanna Kord, Women Peasant Poets in Eighteenth-Century England, Scotland, and Germany: Milkmaids on Parnassus (New York, 2003), 50-51.

4. Literary patronage and plebeian politics figure large in the narrativizing of laboring-class writers' histories, as Kerri Andrews's recent exploration of Ann Yearsley's relationship with Hannah More exemplifies. Andrews's discovery of the original letter Yearsley sent to More following their infamous dispute over the proceeds of Yearsley's Poems in 1785- previously known only from More's highly partial reproduction of it (in a letter to Elizabeth Montagu, in fact) - revealed Yearsley's attempt to vindicate herself through the respectful, albeit assertive, elaboration of her own lower-class perspective. Kerri Andrews, Ann Yearsley and Hannah More, Patronage and Poetry: The Story of a Literary Relationship (London, 2013), 43-44.

5. Katherine G. Hornbeak, "New Light on Mrs. Montagu," in The Age of Johnson: Essays Presented to Chauncey Brewster Tinker (New Haven, Conn., 1949), 349-61 at 350. Elizabeth's husband, Edward Montagu (1692-1776), was a wealthy landowner, MP for Huntingdonshire, and member of the Royal Society; when he fell ill in the late 1760 s, the management of his various estates fell increasingly to his wife.

6. Woodhouse had sought to clear himself of the guilt that dismissal typically implied, stating, "I have been expelled for reasons too tedious to relate" and adding, "They are such as have rendered myself, and my family, twice the outcasts of society, without the conviction, or even the specification, of a crime." James Woodhouse, Poems on Several Occasions, Never Before Published (London, 1788), vii. Woodhouse also wrote Norbury Park and Love Letters to my Wife in 1789, but these were not published until 1803/4 and neither refer to Montagu, directly or indirectly. 
employment in the preface or the poems that followed, Woodhouse was perhaps reluctant to defame his erstwhile patron so publicly or so promptly. Instead, having opened a bookshop at 10 Lower Brook Street, Grosvenor Square, he embarked on a verse autobiography of epic proportions - at 28,013 lines, almost three times longer than Milton's Paradise Lost or Wordsworth's Prelude. Composed throughout the 1790 os but unpublished until long after his death, The Life and Lucubrations of Crispinus Scriblerus (1896) offers an excoriating portrayal of Elizabeth Montagu as a proud, power-hungry, and persecuting "Patroness," in addition to animadversions against class oppression in general.7 This "later 'unpublished' Woodhouse" has rightly fascinated twentieth- and twenty-first-century critics and has been proclaimed "one of the most important literary records of plebeian social and ideological critique of the late eighteenth century."

The critical appraisal of Woodhouse has become overdetermined, however. Critics have starkly divided his early from his later poetry, contrasting their respective style, content, and overall intention. William Christmas claims that there are "essentially two Woodhouses": "One is the sycophant poet hoping to better his lot in life, writing and publishing under the protection of Shenstone, Lyttelton, and the Montagus in the 1760 s," while the other is the 1790 s poet "influenced by 'a rude presumptuous muse, uncheck'd' who begins to see beyond himself." While recognizing the political dimensions of Crispinus Scriblerus, this privileging of Woodhouse's later work for its explicit proto-proletarian strain has contributed to a persistent (mis)characterization of the early poet as, by contrast, a "sycophant extraordinaire."9 Steve VanHagen has recently argued that "Woodhouse's work justifies at least a qualified defence," speculating that there is "perhaps [...] more continuity in Woodhouse's attitudes in his verse-writing career" than critics allow. ${ }^{10}$ Addressing a range of new evidence,

7. Woodhouse published a version of the first chapter of Crispinus Scriblerus anonymously in 1814. Of all seventeen chapters, this contained only the most unobjectionable details about Crispin(us)'s childhood. Thought to have been suppressed by the author for fear of repercussions, the autobiography was only published in full in 1896, by Woodhouse's descendants, in The Life and Poetical Works of James Woodhouse, ed. R. I. Woodhouse, 2 vols. (London, 1896). It fills the entirety of the first volume (chaps. 1-12) and a substantial part of the second (chaps. 13-17). I will refer to this work as Crispinus Scriblerus henceforth, and further references will be cited parenthetically in the text by chapter and line number.

8. William J. Christmas, The Lab'ring Muses: Work, Writing, and the Social Order in English Plebeian Poetry, 1730-1830 (Newark, N.J., 2001), 187, 198.

9. Ibid., 187, 192. More recently, John Goodridge has stated that Woodhouse's 1766 Poems on Several Occasions "seems caught" in the "mesmerizing gaze [...] of patronly beneficence" and concludes, "creeping humility' thus fills the whole volume”; John Goodridge, "Labouring-Class Poetry," in Teaching Romanticism, ed. David Higgins and Sharon Ruston (Basingstoke, U.K., 2010), 11-23 at 17. Earlier examples include Betty Rizzo, “The Patron as Poet Maker: The Politics of Benefaction,” Studies in Eighteenth-Century Culture 20 (1990): 241-66 at 254 ("James Woodhouse, after a long submission, openly rebelled”); and Annette W. Cafarelli, “The Romantic 'Peasant' Poets and Their Patrons," Wordsworth Circle 26 (1995): 77-87 at 79 ("Woodhouse's poetry was a kind of planned parasitism, his patrons were willing hosts").

10. Steve Van-Hagen, "Patrons, Influences, and Poetic Communities in James Woodhouse's The Life and Lucubrations of Crispinus Scriblerus," in Social Networks in the Long Eighteenth Century: Clubs, Literary Salons, Textual Coteries, ed. Ileana Baird (Newcastle upon Tyne, U.K., 2014), 309-33 at 319-20. 
I substantiate Van-Hagen's suspicions and contend that this charge of sycophancyand its suggestion of the socially submissive and even willfully compliant nature of Woodhouse's early poetry-calls for a much more comprehensive confutation.

This study is based on the Montagu Collection at the Huntington Library, which contains fourteen letters written by Woodhouse and at least 100 other letters in which Woodhouse is mentioned, frequently at length. ${ }^{11}$ His less obvious presence in the archive-in the scattered comments, descriptions, and allusions shared by Montagu and her friends-has long remained invisible. Uncovered and assembled, these letters offer unprecedented insights into Woodhouse's life, relationships, and rhetorical style that are essential for understanding his early poetry. Unlike the conspicuous dedications, subscription lists, and panegyric displays of print, epistolary correspondence offers a different, more complex view of the relationships evolving between poet and patron(s), and the compromises and opportunities involved in literary patronage. Focusing on the period between Woodhouse's initial entry into print culture in 1764 and his employment at Sandleford (and the abrupt halt to his literary output) in 1767 , this essay uses personal letters to challenge the conventional account of his literary career as divided into two distinct periods. By exploring the familiar relationships Woodhouse cultivated with his patrons and the radical, evangelical sense of equality he expressed in parallel-in a variety of forms-I argue that he sought patronage at the same time (and often for the same reasons) as he resisted the oppressive status quo.

Far from passive in the construction of his laboring-class literary persona, Woodhouse carefully negotiated polite codes and conventions in order to claim and maintain access to the cultural spaces that his class was typically debarred from-be they landscape, literature, or civil society. Within the privacy of patronage or under the cover of pseudonymity, Woodhouse readily defended himself against the presumptions of class privilege; by contrast, his open forays into the world of print were moments of compromise in which he aired his private views only indirectly. Above all, Woodhouse's attention to the formalities of literary patronage enabled him to modulate his political opinions into a more acceptable, implicit public form. Providing a full reappraisal of Woodhouse's expanded second edition, Poems on Several Occasions (1766), I contend that his frank expressions of gratitude toward his patrons in fact provide a platform for appraising elite behavior. By elaborating on the virtues of his benefactors, in contrast to a wider background of injustice, he not only heightens his praise but also balances it with corrective social commentary. Far from sycophantic, therefore, Woodhouse's conspicuous use of compliment is the principal means through which class-based criticism is inscribed into his early poetry.

11. James Woodhouse to Elizabeth Montagu, MO 6781-94. Two additional letters from Edward Montagu to Elizabeth Montagu include postscripts in Woodhouse's hand ( $M O$ 2049, MO 2104). Three further letters from Woodhouse to Montagu survive in the National Library of Wales (NLW MS 5433 C). Another letter partly written by Woodhouse is MS ENG 1365 (148), Montagu Family Papers 1739-1920, Houghton Library, Harvard University. 


\section{$\sim$ Between Friends and Foes: Rethinking Woodhouse's Early Patronage}

James Woodhouse, the "Poetical Shoemaker," was born in Rowley Regis, in $1735 .{ }^{12}$ Of yeoman stock, with little formal education, he rose to notice as a result of his acquaintance with William Shenstone, the pastoral poet and designer of the famous landscape garden, the Leasowes, which was just two miles away in Halesowen. When Shenstone closed the garden to the public due to instances of vandalism, Woodhouse wrote "An Elegy to William Shenstone" in 1759, petitioning him for access on the basis of a shared enthusiasm for landscape and poetry. Shenstone was impressed, befriended Woodhouse, and over the next four years supported his development as a poet. ${ }^{13}$ Following Shenstone's death in February 1763, the publication of Woodhouse's Poems on Sundry Occasions went ahead with the help of Shenstone's publishers, the Dodsley brothers, and Woodhouse discovered new patrons in the form of Lord George Lyttelton, the owner of the nearby estate of Hagley, and Lyttelton's close "friend and coadjutor," the celebrated bluestocking Elizabeth Montagu. ${ }^{14}$

If Shenstone had welcomed Woodhouse into the realms of poetry, Lyttelton and Montagu ensured Woodhouse would make a name for himself within it. Lyttelton could boast a string of successes as a literary patron, having nurtured such redoubtable talents as Alexander Pope, James Thomson, and Henry Fielding; meanwhile, Montagu's éclat and epistolary networks gave an appreciable boost to the ongoing subscription campaign for Woodhouse's second edition. Following Woodhouse's introduction to the public, as an "honest, sober, industrious Man" of "uncommon Genius," the "Advertisement" to Poems on Sundry Occasions had made an appeal for "Benefactions for the use of the author," promising that "if a second edition should be printed, the names of such shall be inserted." 15 As well as subscriptions, therefore, Montagu solicited charitable donations, the earliest being "3 guineas" from an elderly widow, "Mrs Sherlock," who was on her deathbed. ${ }^{16}$ As Montagu informed her sister, Sarah Scott, by 1765 she had engaged some subscribers "from whom I shall gather about $£ 7$ yearly" and intended with her own contribution to make up an annuity of $£ 15$ for Woodhouse ([January] 21, [1765], MO 5818).17 Of the larger donations, Lord and Lady

12. The most exhaustive critical biography to date is provided by Steve Van-Hagen, "The Life, Works and Reception of an Evangelical Radical: James Woodhouse (1735-1820), the 'Poetical Shoemaker," Literature Compass 6, no. 2 (2009):384-406.

13. As Christmas details, Shenstone granted Woodhouse access to his property, often invited him to his table, shared his poetry with him, "lent him Classics, and other books in English," and introduced him to other literary personages. He did not, however, offer Woodhouse financial relief. Christmas, Lab'ring Muses, 192.

14. The Autobiography of the Rev. Dr Alexander Carlyle of Inveresk 1722-1805, ed. John H. Burton (London, 1910), 484.

15. James Woodhouse, Poems on Sundry Occasions (London, 1764), v-vii.

16. Elizabeth Montagu to William Petty, [May 16, 1764], MO 4631. This letter is printed in Reginald Blunt, Mrs. Montagu, "Queen of the Blues," Her Letters and Friendships from 1762 to 180o, 2 vols. (London, 1923), 1:63-64. Mrs. Sherlock was the second wife of the late bishop of London, Thomas Sherlock, and died on June 23,1764 .

17. This annuity closely matched Woodhouse's original earnings as a shoemaker and local tutor of "not more than eight shillings a week" (as the "Advertisement" to the first edition detailed). This does 
Cardigan gave "ten guineas a piece," and by 1766 Montagu refers to a "goodly sum," which doubtless ran into hundreds of pounds (February 1766, MO 5837). When Poems on Several Occasions arrived in May 1766, readers were met with a strong visual statement of Woodhouse's extensive patronage and gratitude: he dedicated the book to Lyttelton, "As an humble acknowledgement of his condescension, humanity and beneficence towards the author," before thanking an array of 113 "Benefactors" and 280 "Subscribers" - including nobles, gentlemen, clergymen, Royal Society fellows, bluestockings, and writers-the list of whom ran into eight pages. ${ }^{18}$ This sentiment of gratitude is further elaborated in the poems themselves, as all but two of them are addressed to his patrons and praise their talents, virtues, and above all benevolence.

This kind of conspicuous commendation could be read to suggest that Woodhouse experienced patronage as scholars generally conceive of it: as a fundamentally economic transaction in which money and guidance for the poet is exchanged for a range of cultural "goods" for the patron-namely praise, fame, and magnificence. ${ }^{19}$ However, epistolary correspondence like that by, to, and about Woodhouse can offer a quite different perspective on literary patronage. As Markman Ellis observes, "correspondents establish obligations of friendship and patronage by sending and receiving letters. Most familiar letters have no utility or economic value: or rather, their utility is their role in establishing and maintaining friendship." ${ }^{20}$ Central to cultivation of Woodhouse's relationship with Lyttelton and Montagu, such familiar letters complicate the notion of patronage as a primarily economic transaction and suggest that Woodhouse also received from his patrons much of emotional value.

The formative influence Shenstone had on Woodhouse's poetic development has been helpfully particularized by Sandro Jung, yet a sense of literary collaboration seems also to pertain to Woodhouse's association with Lyttelton and Montagu. ${ }^{21}$ As writers and critics, Lyttelton and Montagu not only shaped his reading but also offered him incisive editorial assistance, not to mention encouragement. ${ }^{22}$ In his earliest sur-

not take into account the free school worth $£ 10$ per annum subsequently presented to him by Lord Dudley in the spring of 1764 . Woodhouse, Poems on Sundry Occasions, vi, 109.

18. James Woodhouse, Poems on Several Occasions. The Second Edition, Corrected, with Several Additional Pieces Never Before Published. To the Whole is Prefixed, a List of his Generous Benefactors on the Former Publication, and the Subscribers to the Present Edition (London, 1766). Notice appeared in the St. James's Chronicle 818 (May 31, 1766).

19. Griffin, Literary Patronage, 13, 18-39.

20. Markman Ellis, "Reading Practices in Elizabeth Montagu's Epistolary Network of the 1750s," in Bluestockings Displayed: Portraiture, Performance and Patronage, 1730-1830, ed. Elizabeth Eger (Cambridge, 2013), 213-32 at 216.

21. Sandro Jung, "Shenstone, Woodhouse, and Mid-Eighteenth-Century Poetics: Genre and the Elegiac-Pastoral Landscape," Philological Quarterly 88, no. 2 (2009): 127-49. See also Sandro Jung, "Mentorship and 'Patronage' in Mid-Eighteenth-Century England: William Shenstone Reconsidered," Bulletin de la Societe détudes anglo-americaines des XVIIe et XVIIIe siècles 54 (2002): 187-98. For more on this alternative concept to patronage, see Mentoring in Eighteenth-Century British Literature and Culture, ed. Anthony W. Lee (London, 2013).

22. Woodhouse received gifts of books from Montagu (June 5, 1764, MO 6376; August 8, 1764, MO 1433) and also had access to Lyttelton's library-evidently knowing it well enough to be asked to make a "catalogue of his Books" (November 27, 1766, MO 6787). His surviving letters to Montagu 
viving letter to Montagu, Woodhouse recounted how Lyttelton had inquired "after the Progress of my Muse, promising the use of his Judgment in the correction of any of my M. S. Productions." Having "accordingly sent his Lordship Two Elegies to Mr. Shenstone's memory, \& an Ode to Mrs. Montague," Woodhouse described how they stood up to his "penetrating Criticisms":

One of the Elegies escap'd, with the purloining of a few stanzas \& the condemnation of some particular words; the o[ther] diminish'd in size till it was no longer an Elegy, [\& the] Ode I intended for you, Madam; dwindled into the Form of an Epigram. (August 26, [17]64, MO 6782)

According to Woodhouse, Lyttelton was primarily concerned with his diction. He explained, "The Terms trite, Commonplace \&c. are terrible sounds in a Poet's ears [...]. But when his Lordship began to apply to some Parts the appellation of new Thoughts, \& added the endearing epithets of pretty, pathetic \&c. I began to feel the stripes heal." The corrected poems were then forwarded to Montagu "in their present pigmey size." Although Lyttelton had advised him to incorporate the remaining stanzas of the second elegy into the first, Woodhouse admitted that "as the disparity of the measure made it not so easy, I have not since had leisure to do it, but have sent them in their original Form." If Montagu too supplied a critique, Woodhouse would have had not one but two sets of revisions, and presumably some advice as to how the elegies might be combined. Woodhouse was understandably pleased to receive these interventions; one of his earliest reviewers had declared, "that kind of descriptive poetry which he aims at, is become so common" that "it must require very great genius to make any considerable figure in poetry; and we cannot compliment Mr. Woodhouse with any encomium beyond that of exhibiting a phænomenon." 23 In this critical climate, the psychological effect of his patrons' "Encouragement" was significant. ${ }^{24}$ As he added:

I cannot help thinking myself born in an unhappy Era, for a Poet; when, to give one that Title, it is requisite to travel out of every beaten Track; which, as there are so many candidates for the Muses, in the present age; \& so many gone before; \& as the Temple of Fame is situated at so great a Distance [...]. Yet have I been so fortunate as to meet with Encouragement from some [of] the most eminent Personages of the present age; in front of whom, without Hesitation, (since I have heard her Character from the Mouth of Lord Lytteln.) I place Mrs. Montagu. (August 26, [17]64, MO 6782)

contain musings about aesthetics, the sublime and the beautiful, the authenticity of Macpherson's Ossian, and discussions of prominent intellectuals such as Burke, Hume, and Rousseau.

23. Critical Review 17 (May 1764): 393.

24. Johnson defined encouragement as "incitement to any action or practice" as well as "Favour; countenance; support”; Samuel Johnson, A Dictionary of the English Language, 2 vols., 4th ed. (London, 1773). 
After Shenstone's death, rather than in a one-on-one relationship, Woodhouse's literary activity took place within a small coterie. Emendation went hand in hand with encouragement; moreover, epistolary correspondence was interwoven with poetic composition. ${ }^{25}$ As Woodhouse subsequently informed Montagu, "At Evening I write to you, or Mr. Bridgen; or transcribe, or correct some of my poetical Trifles." $26 \mathrm{Al}$ though he could occasionally visit Lyttelton at Hagley, until 1767 his contact with Montagu was largely restricted to letters. Woodhouse's patrons thus formed the basis of an influential intellectual community for the otherwise isolated and even intimidating activity of literary composition-particularly for a provincial, plebeian poet. ${ }^{27}$

\section{旁色}

While it may be the case, therefore, that Woodhouse's gratitude toward his patrons was more genuine than the charge of sycophancy would suggest, there are other, more important revelations about Woodhouse that require us to reconsider the question of sycophancy altogether, as well as the nature of his early poetry. As a recent documentary discovery from the Huntington Library reveals, during one of his customary walks in the Leasowes in 1765, Woodhouse was mistaken for a trespasser and set upon by a certain "Captain Turnpenny," who had purchased the estate shortly after Shenstone's death. The description of this event, and Woodhouse's subsequent response to it, tell us much about the class prejudices he continued to face both within and beyond the special relationship of patronage; moreover, the episode reveals a striking difference between the public and private manifestations of Woodhouse's increasing opposition to forms of social oppression.

Woodhouse's admission to the Leasowes was central to his early experience of class distinction, placing him precariously between his betters and those of his own class. Following his appeal to Shenstone in 1759 , Woodhouse was given a key to the Leasowes. As he described in the second elegy to Shenstone, this symbol of "free access"

25. This was not the only occasion upon which Woodhouse consulted his patrons. The following year Woodhouse enclosed to Montagu "some of my M.S.S. of which I also beg your Opinion, \& Corrections" (April 17, 1765, MO 6783). For more on Elizabeth Montagu's practice of coterie patronage, see Eve T. Bannet, “The Bluestocking Sisters: Women's Patronage, Millenium Hall, and 'the Visible Providence of a Country," Eighteenth-Century Life 30, no. 1 (2006): 25-55 at 45.

26. Edward Bridgen (d. 1787), listed at the end of the "Advertisement" in Poems on Sundry Occasions as a "Merchant of Lovell-Court, Paternoster Row, London," was Woodhouse's friend and acted in some capacity as his agent. According to Woodhouse, after the first issue of his Poems sold out, Bridgen inquired whether he wished "to hazard another Impression of 250 next Winter" (MO 6782). Woodhouse wrote regularly to Bridgen (MO 6783, April 17, 1765) and visited him in London (MO 6786, November 7, 1766).

27. Throughout the eighteenth century the sociable circulation of manuscripts remained an important aspect of literary composition, especially for provincial writers. See Margaret J. M. Ezell, Social Authorship and the Advent of Print (London, 1999). Although no other letters by Woodhouse are known to survive beyond collections of Montagu's correspondence, he appears to have maintained a wide and regular correspondence with family and friends, as well as publishers and other business acquaintances, many of whom were based in London. 
prevented his presence in the gardens' being perceived as trespass; although this left no "occasion to transgress," Woodhouse's admission nevertheless occasioned an awareness of limits. Indeed, he reproached those "ruthless crowds, disdaining bounds" who had abused Shenstone's generosity and vandalized the gardens. ${ }^{28}$ Much like literary patronage, the key is a token of allowance from a higher authority that granted Woodhouse certain privileges while demanding his continued observance of the barriers that necessitated this special dispensation - namely, social inequality. Bridget Keegan summarizes the paradox thus: while Woodhouse's garden poetry "seeks to claim aesthetic and ultimately political rights for the poet," landscape remains "both the site of class distinctions and a place where those divisions might be equalized."29

Woodhouse's circumvention of traditional class boundaries in the Leasowes was short lived. Even as he was in the middle of his longest attempt at loco-description, "The Lessowes. A Poem," Shenstone's death spelled the end of this egalitarian vision. Without a protector, the destructive forces of the outer world threatened both garden and poet: the "woodman's stroke" (line 1211) is imaginatively coupled with Woodhouse's lyre, lying in "scatter'd fragments" (line 1243). This gloomy vision is further developed in "Wrote at the Lessowes, After Mr. Shenstone's Death," which marks a significant shift in his attitude toward the garden. As Jung observes, "Woodhouse relates Shenstone to the genius loci without which the landscape becomes barren and uncanny." 30 Mourning the loss of a mentor, he also laments the loss of a landscape. The adjacent lines in the poem, "I love because he lov'd / 'Twas not these scenes that pleas'd alone" (lines 8-9), imply that the Leasowes had aesthetic and social impor tance. With Shenstone's demise, therefore, Woodhouse imagines the loss not only of a landscape but also of a place where class distinctions were suspended-where leisure, reflection, and literary pursuits were not deemed inappropriate for the aspiring artisan but actively encouraged.

Woodhouse does not reveal in his early poetry how soon this dwindling ideal was violently ruptured - and by the reinstatement of class-based differences at that. In August 1765 Montagu wrote to Lyttelton, "I am a little concern'd that I have not heard from our friend Mr Woodhouse." Aware that he had recently visited Lyttelton at Hagley, she "wish [ed] his silence may be owing to his being busy at harvest," adding:

[I]t is certainly no disgrace to our Bard to work at the harvest for his Father, but few men of his rank, who had been so much taken notice of by the World, would have had the noble and sublime humility to turn

28. James Woodhouse, "Elegy II. Written to William Shenstone, Esq; of the Lessowes," in EighteenthCentury English Labouring-Class Poets 1700-180o, vol. 2, 1740-1780, ed. Bridget Keegan (London, 2003), 151-53, lines 17-18, 47. This anthology reproduces all but one poem ("Spring”) from Woodhouse's expanded second edition, Poems on Several Occasions (1766), in the original order; it also includes most of the prefatory material and additional notes - see pages 144-211, 406-14. Further references to Woodhouse's early poems will be taken from this volume and cited parenthetically in the text.

29. Bridget Keegan, British Labouring-Class Nature Poetry, 1730-1837 (Basingstoke, U.K., 2008), 38,47 .

30. Jung, "Shenstone, Woodhouse, and Mid-Eighteenth-Century Poetics," 142. 
labourer. Where did he get greatness of mind enough to be above pride? (August 12, 1765, MO 1440)

A woman of considerable standing for whom manual labor was naturally associated with lowliness, Montagu was amazed that Woodhouse could deign to help his father with the harvest. Since Woodhouse had been elevated by Lord Dudley's gift to the position of schoolmaster, Montagu considered such work technically beneath him (though she was nevertheless pleased to find that he did not disown his rustic roots). Her remark, however, indicated the incommensurability of different class-based understandings of pride. While for Montagu pride was a sense of personal prestige based on birth, wealth, and status, for Woodhouse it was a belief in human dignity regardless of rank. This developing plebeian definition of pride (comparable to the modern emphasis upon "self-respect") was most clearly propounded by the milkmaid-poet Ann Yearsley (1753-1806), who later in the century would protest openly to her patron, Hannah More, "You found me poor yet proud, if it can be calld pride to feel too much humbled by certain obligations, and above submitting to servility." 31 While he avoided the highly public and confrontational form of complaint that Yearsley would pursue, there was nonetheless a privately politicized aspect to Woodhouse that epistolary correspondence reveals. ${ }^{32}$ Responding to Montagu's concerns, Lyttelton penned one of the longest single accounts concerning Woodhouse in the Montagu Collection, here printed for the first time (figs. 1-4):

My Neighbour at Rowley, who I hope will make a Poet in time, has lately met with a misfortune to which Poets are liable, that of being beat; but he did not deserve it half so well as most of them do; for he never libelld Man or Woman! I presume your blood rises, and begins to glow in your Cheeks; your Eyes sparkle with Indignation, and you say to yourself, how? My Hero beat! Yes, madam, all your Heroes are not Emins:33 yet I

31. Quoted in Andrews, Patronage and Poetry, 43. Johnson defines pride as "inordinate and unreasonable self-esteem," while modern dictionaries emphasize "a feeling of honour and self-respect; a sense of personal worth." Johnson, Dictionary; Collins English Dictionary, 12th ed. (Glasgow, 2014). Although Johnson gives an additional definition of pride as "Elevation; dignity," and Collins "Excessive self-esteem," the development of the word's primary signification suggests a subtle, positive shift in meaning over time.

32. Andrews, Patronage and Poetry, 55. Yearsley added a printed "Narrative" describing her controversial fallout with Hannah More in her fourth edition of Poems on Several Occasions (1786).

33. Joseph Emin (1726-1809) was a prominent figure in the Armenian national liberation movement whose story of adventurous, patriotic struggle attracted the attention of various British elites and intellectuals. Lyttelton commissioned his portrait, and Montagu regularly corresponded with him. Emin addressed her as "My Queen of Sheba," describing himself as her "Persian Slave whom you have been pleased to honour with the Title of Hero." By 1765 Emin had served for five years as a gentleman officer and distinguished himself in the Seven Years' War as a volunteer. Lyttelton may have been referring to Emin's anecdote of a man "three times as big as himself" whom he brought down with "a single slap." See Michael H. Fisher, Counterflows to Colonialism: Indian Travellers and Settlers in Britain, 1600-1857 (New Delhi, 2004), 73, 77-79. 


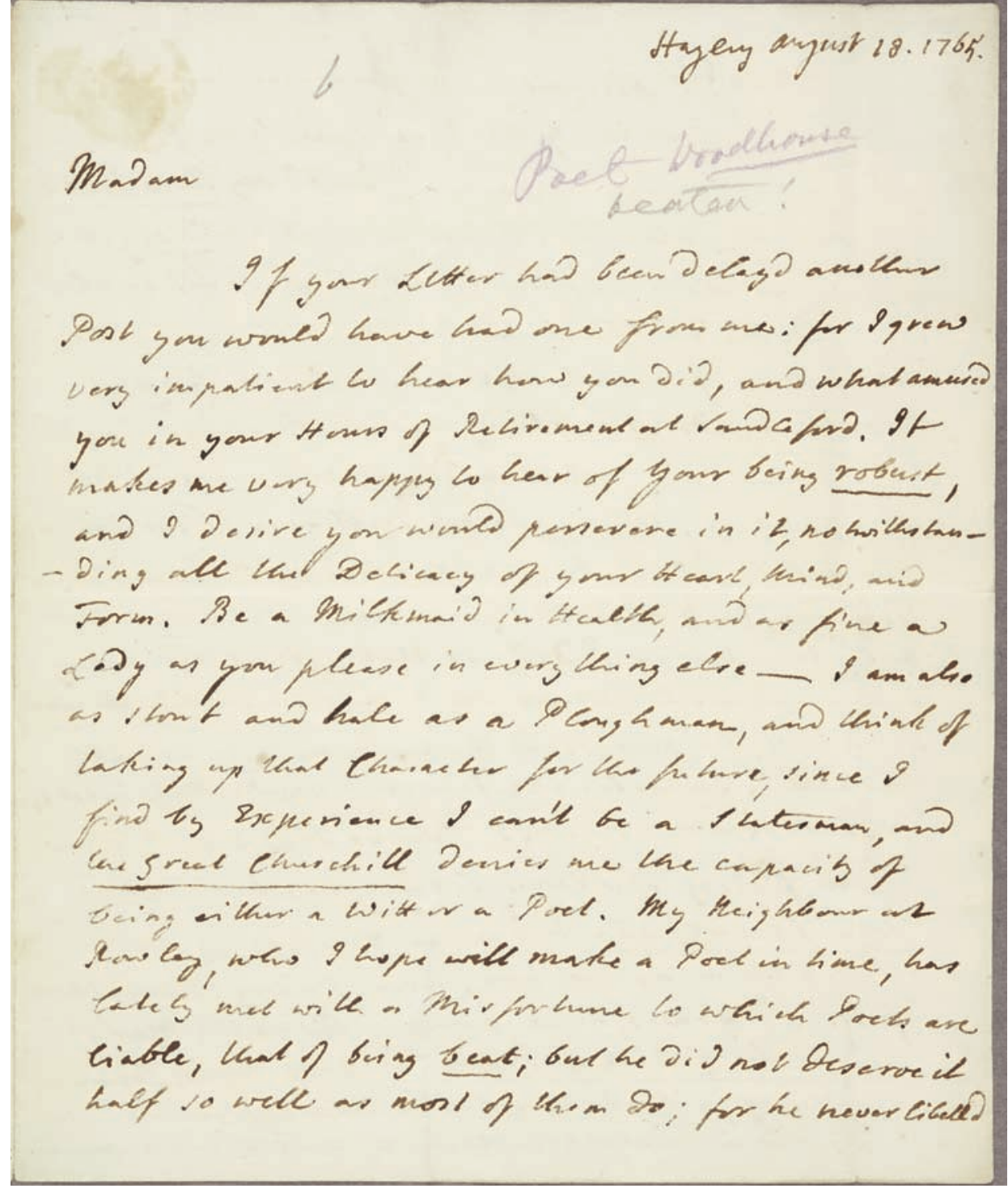

FIGU RE 1. George Lyttelton to Elizabeth Montagu, August 18, 1765, MO 1334, p. 1. Montagu Collection, Huntington Library. The note at the top of the letter, "Poet Woodhouse beaten!" (in pencil, in two different shades), is likely the addition of one of the early editors of Montagu's letters. 
man or Woman! g preinme your beovd rives, and begion,

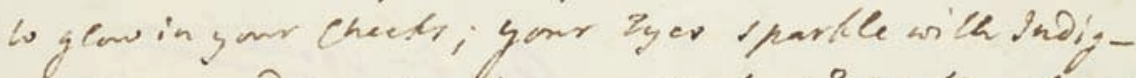

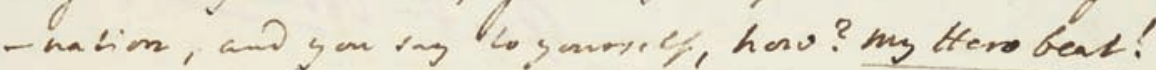

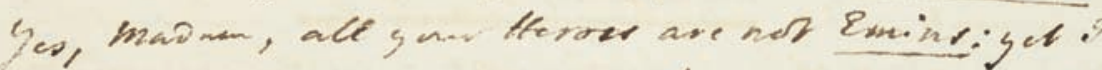
apure gove kare was the true hervical freind in what

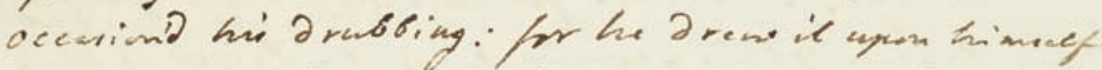
anc of pure fratarial abection, to rave a Bulaer

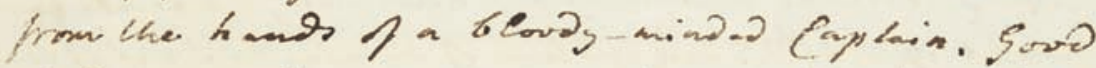
torl, yne willery, what a thange tharg in lasi! hol

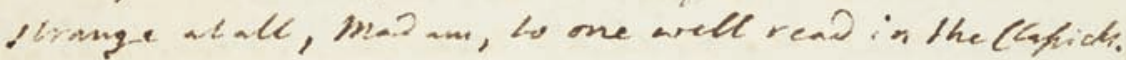

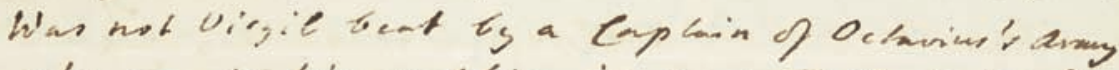
who carybe him watking in some Tiecs cealda.? once baen his ows? Dit nol that gallent officer on

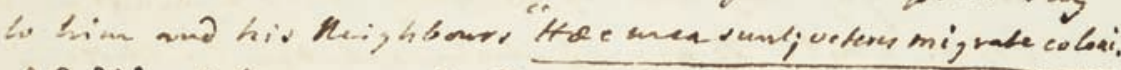

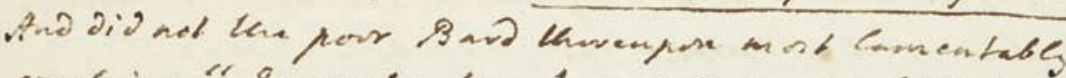
ercalaim "9mprobu. hoe tam culla novalia mitis habebit,

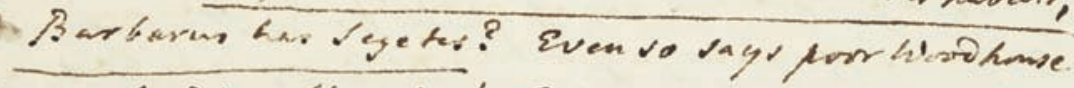
upon finding theoveme's kefors, to which he had

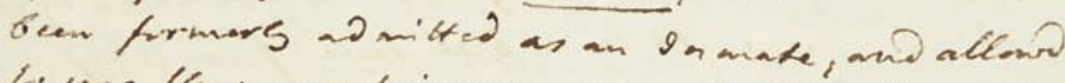
he ere lenm as his som, upen finding. Oray, those

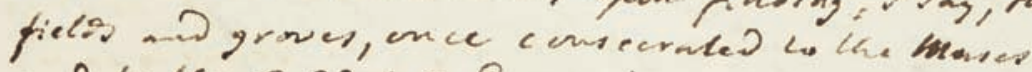
and to the 5-20\% of Peace, in periesion of Caphin Turmpenny, a barberoms Solk, who having forsididen

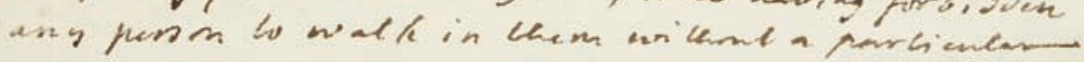

FIGURE 2. George Lyttelton to Elizabeth Montagu, August 18, 1765, MO 1334, p. 2. Montagu Collection, Huntington Library. 
ficense, and meeting him wo hir broller, will nolles companion, there, hipl up his brother's heele, ano when the Bard in Lerpsed called in che aid of hi:

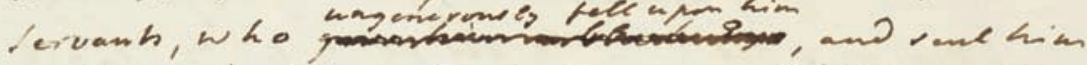
A. Dophe' with a berods bese, a rweled Face, wD a

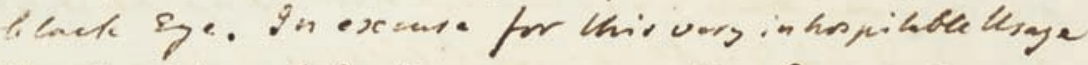

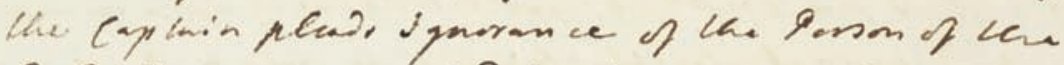

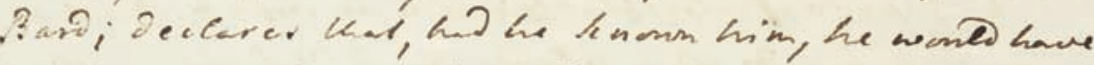

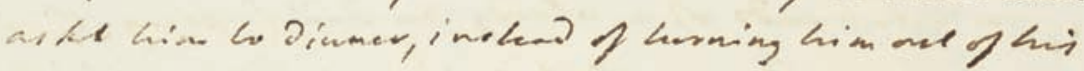

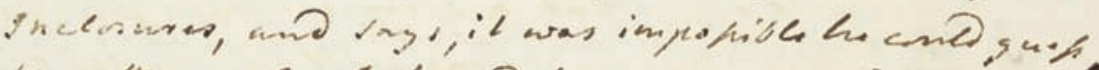

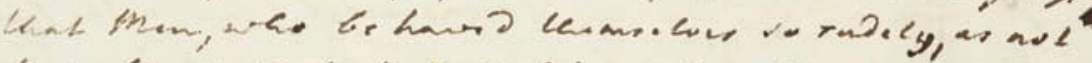

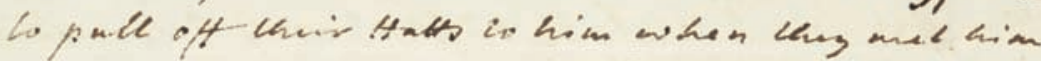

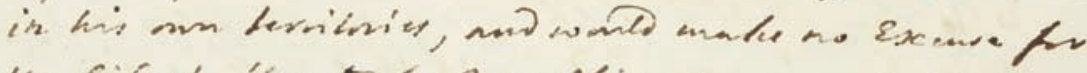

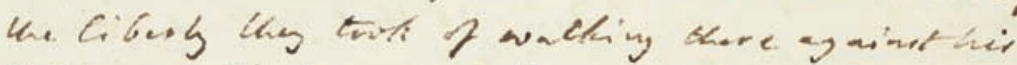

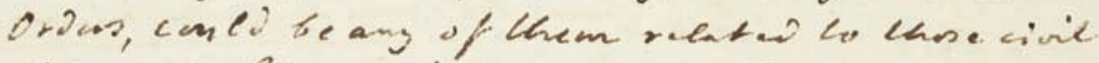

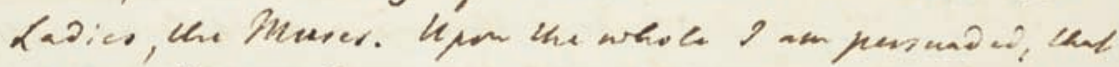
it ke. Poel had anaved himself, or given ang mark of tir chameler, when he war gring bo be bead, as lle

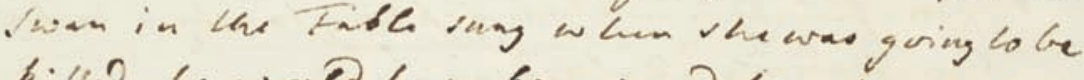
killed, he woned have been raved friser ias fire of.

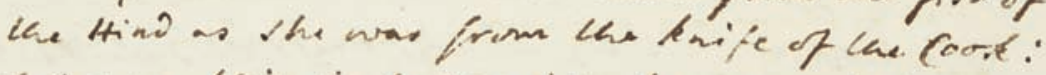

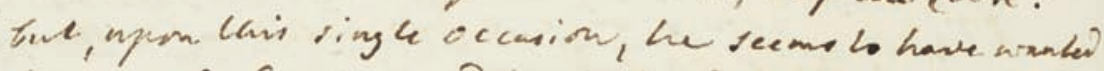

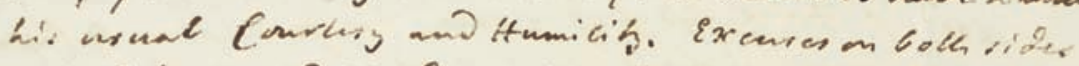
nille o hope end the 2uarvel, and restare him to the fiea

FIGURE 3. George Lyttelton to Elizabeth Montagu, August 18, 1765, MO 1334, p. 3. Montagu Collection, Huntington Library. 
We of the Lefious. But, ar 9 have not lese pouser waich

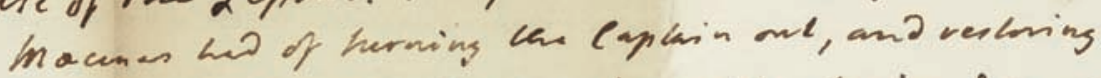
lear bs ceat means to onr fawousite Javin, I nuese

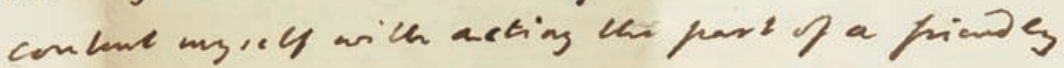
Inviador, and getting the Sater opend ho him, notas as

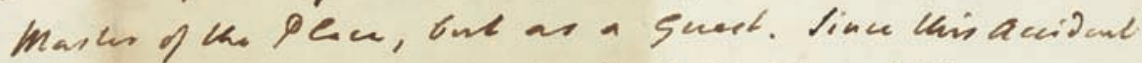
I have vilited him, and frumb Goll him mo Daphere

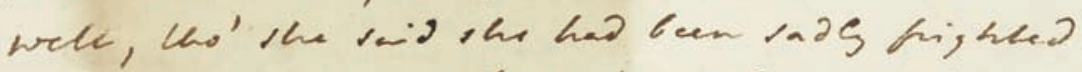

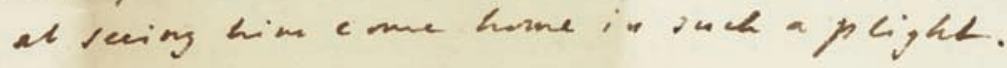

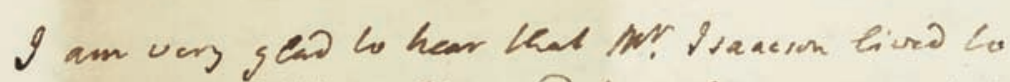
firist the hiring'. It wond have been vory un firturate

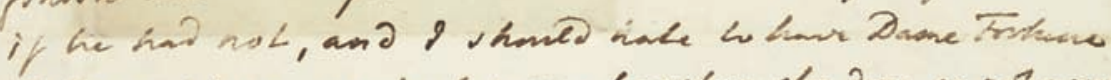
tate a pique ageint you, forwhen she doer vo notoots We wisom of Ininerva can secure one againther

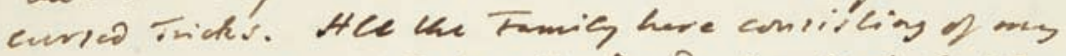

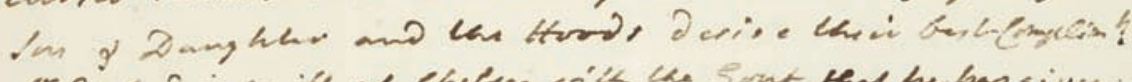

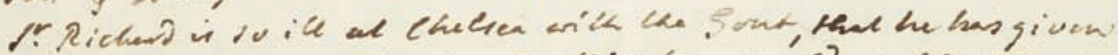

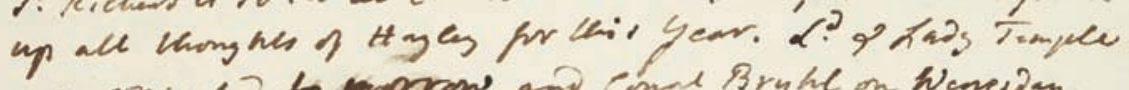
ere expectio to monom, and Cond Bruhl on Weneiday. My Im will wrike to gon tore. I am mench concerno for

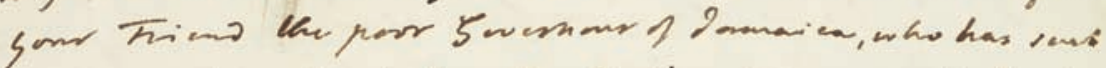

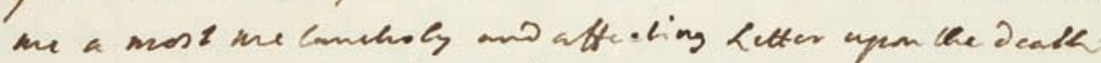

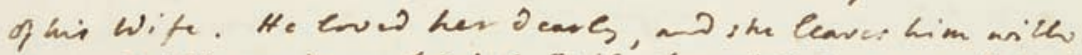
three Cailorm in a kind of Buib from hi Coman. Wrikls

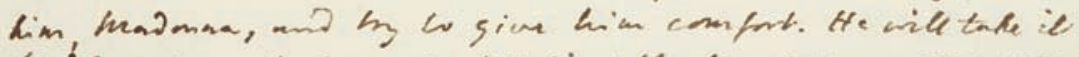

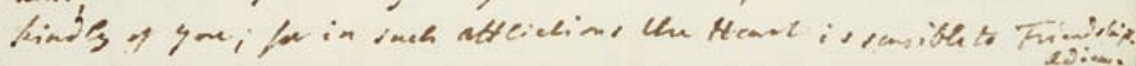

FIGURE 4. George Lyttelton to Elizabeth Montagu, August 18, 1765, MO 1334, p. 4. Montagu Collection, Huntington Library. 
assure you there was the true heroical spirit in what occasion'd his drubbing: for he drew it upon himself out of pure fraternal affection, to save a Brother from the hands of a bloody-minded Captain. Good Lord, you will cry, what a strange story is this! Not strange at all, Madam, to one well read in the Classicks. Was not Virgil beat by a Captain of Octavius's army who caught him walking in some Fields that had once been his own? Did not that gallant officer say to him and his Neighbours "Haec mea sunt; ueteres migrate coloni. ["] And did not the poor Bard thereupon most lamentably exclaim "Improbus haec tam culta noualia miles habebit, Barbarus has segetes?[”]34

Following this sophisticated preamble, Lyttelton describes what had happened:

Even so says poor Woodhouse upon finding Shenstone's Lessows, to which he had been formerly admitted as an inmate, and allowd to use them as his own, upon finding, I say, those fields and groves, once consecrated to the Muses and to the Goddess of Peace, in possession of Captain Turnpenny, a barbarous Goth, who having forbidden any person to walk in them without a particular Licence, and meeting him and his brother, with another Companion, there, tript up his brother's heels, and when the Bard interposed called in the aid of his servants, who < gave him a black Eye [?]> I ungenerously fell upon him/, and sent him to Daphne with a bloody Nose, a swelld Face, and a black Eye. 35 In excuse for this very inhospitable usage the Captain pleads ignorance of the Person of the Bard; declares that, had he known him, he would have askd him to dinner, instead of turning him out of his Inclosures, and says, it was impossible he could guess that men, who behaved themselves so rudely, as not to pull off their Hatts to him when they met him in his own territories, and would make no Excuse for the liberty they took of walking there against his Orders, could be any of them related to those civil Ladies, the Muses? Upon the whole I am persuaded, that if the Poet had named himself, or given any mark of his character, when he was going to be beat, as the swan in the Fable sang when she was going to be killed, he would have been saved from the fist of the Hind as she was from the knife of the Cook: but, upon this single occasion, he seems to have wanted his usual Courtesy and Humility. Excuses on both sides will I hope end the

34. These Latin lines translate, respectively, as: "This property is mine; old tenants, out!" and "Shall some godless veteran own this fallow tilth, / These cornfields a barbarian?" Guy Lee, Virgil's Eclogues: The Latin Text with a Verse Translation and Brief Notes (Liverpool, 1980), 57, 11.

35. Daphne was the pet name of Woodhouse's wife, Hannah (Fletcher) Woodhouse (ca. 1743180o), whom he had married in 1760 . It should be kept in mind that Woodhouse, at "six foot six inches," was remarkably well-built for his profession; to have sustained such injuries, he and presumably his friend and his brother, Joseph (b. 1744), must have fully committed to the fray. See Van-Hagen, "Life, Works and Reception," 386. 
Quarrel, and restore him to the free use of the Lessows. But, as I have not the power which Maecenas had of turning the Captain out, and restoring them by that means to our favourite swain, I must content myself with acting the part of a friendly Mediator, and getting the gates opend to him, not as a Master of the Place, but as a Guest. Since this accident I have visited him, and found both him and Daphne well, tho' she said she had been badly frighted at seeing him come home in such a plight. (August $18,1765, \mathrm{MO} 1334$ )

According to this letter, the new owner of the Leasowes (having come into possession in April that year) took an instant dislike to the peregrinations of a trio of countrymen who failed to pay their proper respects to him. ${ }^{36} \mathrm{He}$ made for Woodhouse's brother, Woodhouse "interposed," and the matter getting heated, Turnpenny called in the aid of his servants. They dispatched the matter on his behalf and Woodhouse was sent home bloody and bruised. Given that this summary of events comes from Lyttelton's aristocratic point of view, sorting out what actually happened and interpreting Woodhouse's actions is difficult, and various gaps require filling. Although Turnpenny later pled ignorance of Woodhouse, it is unclear whether Woodhouse recognized Turnpenny as the new owner or whether Turnpenny identified himself as such to the trio. Lyttelton's pithy narration suggests that Turnpenny's attempt to "trip up" Woodhouse's brother was unforeseen and that Woodhouse instinctively defended his brotherwithout thinking about the position of the assailant—but it seems that tensions may have been high in advance of the conflict. Woodhouse would almost certainly have been aware of the new ownership of the estate, given his vicinity to and interest in the place. His failure to introduce himself to Turnpenny (as he had to Shenstone), and his sudden encounter with him in the Leasowes, therefore, suggests not only his disregard of Turnpenny's "forbidd[ing] any person to walk in them without a particular Licence" but also a more profound reluctance to acknowledge his authority. As well as a "barbarous Goth," Shenstone's contemporaries sardonically described Joseph Turnpenny as "a button maker, who was possessed of three thousand pounds, and was willing also to be possessed of taste and genius," and it would not have been surprising if Woodhouse too harbored doubts about this nouveau-riche proprietor. 37 Assuming it was not a stealth attack and that the two groups were aware of one another's presence in the Leasowes, it is unlikely that Woodhouse would not have recognized (or at least suspected) that this was the new owner approaching them, unless he had wanted not to. With tensions thus raised, Turnpenny's instigation of violence against Woodhouse's brother (hardly gentlemanly behavior, after all) may have given license for retaliation as much as defense.

36. Joseph Turnpenny purchased the Leasowes from Shenstone’s cousin for $£ 3,350$ and took possession in April 1765. Turnpenny later sold the estate "to Richard Powel, a Liverpool merchant in the African slave trade" who entered upon it on August 13, 1769. Notes and Queries, 3rd ser., 12 (1867): $288-89$ at 289.

37. "On the Tenants of the Leasowes" in The Miscellaneous Works of Oliver Goldsmith, ed. David Masson (London, 1908), 344-45. 
While this appears to me the most plausible interpretation of the conflict, its significance is elided in Lyttelton's particular elaboration. Overall, he appears surprised at this occurrence and is unable to reconcile it with the more deferential Woodhouse he was used to. Like Montagu, Lyttelton perhaps misunderstood Woodhouse's plebeian "pride" and so downplayed the potential social dimensions of this conflict. For what is meant to be a sympathetic consideration of unjustified violence, Lyttelton's mockheroic tone is disturbing. Beginning archly, claiming that "Poets are liable [...] of being beat," Lyttelton diminishes the seriousness of Woodhouse's "misfortune" and ascribes to it a commonness that overlooks its actual provocation. Poet beatings were not unheard of in the eighteenth century: Alexander Pope had been dogged by the story of his supposed "revenge-whipping," in Ham Walks, by two gentlemen he had lampooned. ${ }^{8}$ Yet that this is an example of class conflict is clear from the fact that Turnpenny felt justified in attacking trespassing rustics, but had he not mistaken the "Person of the Bard" - with his public reputation and connections-he would instead have "askd him to dinner." What baffles Lyttelton most is not the captain's severity, however, but Woodhouse's not diffusing the situation altogether. He is "[u]pon the whole [...] persuaded, that if the Poet had named himself, or given any mark of his character, when he was going to be beat [...], he would have been saved." Lyttelton thus portrays Woodhouse as a victim—rather than as an active participant in, or even provocateur of, the fight. When Lyttelton goes on to explore the "excuse[s]" of the captain (presumably he received Turnpenny's version of events also), his sympathies appear to be further strained. If Woodhouse is the innocent injured party, Turnpenny is a rightly insulted proprietor. Both, it appears, were culpable of impoliteness in allowing a seemingly minor incident to escalate into violence. Woodhouse behaved "rudely" and Turnpenny was "very inhospitable."

Although Lyttelton did not perceive it himself, or rather chose not to, this quarrel was a tipping point at which Woodhouse's sensitivity to injustice took precedence over the "usual Courtesy and Humility" he displayed toward his social superiors. As an instance of intemperate resistance, it not only reveals a previously unrecognized aspect of Woodhouse's character but also indicates the kind of attitudes that he had to moderate in his early works. While there is no evidence that Woodhouse ever visited the Leasowes again, Lyttelton - "acting the part of a friendly Mediator" - appears to have effected some kind of reconciliation, since "Joseph Turnpenny Esq; of the Lessowes" subsequently appeared in the list of subscribers to Poems on Several Occasions. Perhaps Turnpenny was persuaded that this subscription would be a rather more decorous display of his ownership of the Leasowes. 39 At any rate, for the button-maker hoping to turn his wealth into "taste and genius" and the laboring-class poet seeking acceptance in

38. Pope, however, denied the incident described in A Popp upon Pope (1728), stating in a news paper that he had been at home the entire time. See J. V. Guerinot, Pamphlet Attacks on Alexander Pope, 1711-1744 (London, 1969), 115-16.

39. For a useful discussion of the socio-cultural dimensions of subscription, as a fashionable form of financial contribution that "endowed particular prestige" upon subscribers, since it "conveyed the image of a selfless benefactor, interested in public rather than private improvement," see Peter Borsay, The English Urban Renaissance: Culture and Society in the Provincial Town, 1660-1770 (Oxford, 1989), 251-52. 
the literary world, the scuffle was an embarrassment that was best disguised. Further mention of this story appeared neither in Woodhouse's early poetry nor in letters by him or his patrons (who may have restricted its circulation, wishing to avoid the kind of desultory rumors that, for example, Pope was forced to dispel in 1728). Yet despite this smoothing over of the incident, Woodhouse did not forget-or forgive. A mysterious reference to edenic expulsion in Crispinus Scriblerus, previously attributed to Shenstone's original closure of the gardens, now speaks volubly. If Woodhouse had imagined the "social Virtues vanish'd" from the Leasowes following Shenstone's death,

This poor Crispinus prov'd, in after-time, When, without semblance of the simplest crime, In those once-lov'd Domains, from Demon, felt, With fiend-like fury by fierce Despot dealtA Savage! who, those lovely Scenes possess'd, Before, by Innocence, and by Friendship, bless'd!

He felt astonish'd at a fate so strange-

Debarr'd about those woods, and walks, to range, Where oft he'd calmly prowl'd with conscious pride, And hail'd each beauty by kind Shenstone's side; While His kind converse added new delight, To all that caught the ear, or claim'd the sightBut when such vile, outrageous, violence, With savage force, had, thus, expell'd him thence, He found his Soul despise, his Heart deplore, The Scenes whence purest pleasures flow'd before!

(Crispinus Scriblerus, chap. 1, lines 931-53)

An extremely telling document, Lyttelton's 1765 letter exposes something of the tensions lurking behind Woodhouse's early (and also later) poetry, as well as the speed with which class difference could reassert itself, even for the patron-protected poet. Nevertheless, it shows Woodhouse forcefully resisting oppression and refusing to announce his polite credentials in order to dodge a beating. Remaining anonymous and unidentified, he was able to respond unrestrainedly, and perhaps ill-advisedly, to the "vile, outrageous, violence" of a tyrant. If not for Lyttelton's letter, evidence of this remarkable occurrence would have been altogether lost, and we would still have little appreciation of the fraught social realities that Woodhouse was beginning to confront in the 1760 - -in his life, his letters, and his poetry.

\section{勉}

In 1766 Woodhouse's letters to Montagu underwent a subtle but decided change. Though remaining highly respectful in tone, they began to incorporate sentiments that 
verged on the tendentious and even egalitarian. In his recent article on Crispinus Scriblerus, Van-Hagen discusses Woodhouse as a "master social networker" whose "talent for making friends and sharing common interests" played no small part in his success as a writer. He argues that in his autobiography Woodhouse "constructs an ethics of sociability" associated with his "transgressive desire to elide socially-constructed, classbased differences," but such a desire can be traced back to his earlier letters. $4^{40}$ As various critics have noted, the familiar letter was a more informal, spontaneous style of epistolary writing that, although based originally on classical precedents, was becoming increasingly normalized by mid-century; not limited to the correspondence of close friends or family, this familiar style reflected and reinforced emerging practices of sociability and politeness, and emphasized the importance of fidelity but also frankness. ${ }^{41}$ The familiar letter thus offered new opportunities to reconfigure, and even controvert, established conventions and rules of address, which proved enabling for laboring-class writers. As I argue, Woodhouse's manifest ability in the epistolary formMontagu later terms his letters "masterpieces" ([October 4, 1778], MO 6042)—allowed him not just to establish commonalities between himself and his patrons but also to broach potentially confrontational issues in a disarming and even charming manner.

Although in his earliest letters to Montagu Woodhouse displayed a naiveté about the proper forms of introduction, apologizing for the "ungenteel Familiarity [...] from a Person in my Station, to One in so elevated a station as you," he redeemed the "Freedom of [his] Address" by expressing confidence that her "Penetration would attribute it to a right cause; that of my Ignorance of the World, \& the Warmth of my Gratitude" (August 26, [17]64, MO 6782). Like other laboring-class poets, Woodhouse was able to write courteously; more than this, however, he could use the discourse of familiarity to assert himself in a culturally acceptable manner. ${ }^{42}$ The clever exoneration of his "boldness" by an appeal to his patrons' magnanimity, as in the example above, was a strategy he had used in his first verse epistle to Shenstone. By professing confidence in his patrons' forgiveness of his "Freedom," and moreover in their attribution of any objectionable sentiments "to the right cause," Woodhouse could contain his progressive egalitarian attitudes within the bounds of patronal allowance.

Following the publication of Poems on Several Occasions, Woodhouse was offered the position of land bailiff at Sandleford. 43 In his formal acceptance letter to Montagu, written in late 1766 , Woodhouse addressed the problematic question of the

40. Van-Hagen, "Patrons, Influences, and Poetic Communities," 320-21.

41. The Familiar Letter in the Eighteenth Century, ed. Howard Anderson, Philip B. Daghlian, and Irvin Ehrenpreis (Lawrence, Kans., 1966), 271. This "more intimate and subjective style" was also enabled by postal improvements; see T. C. W. Blanning, The Culture of Power and the Power of Culture: Old Regime Europe, 1660-1789 (New York, 2002), 132.

42. As Kerri Andrews claims, Yearsley was "quite capable of writing courteously and civilly [...] maintaining the proper forms towards her patron," even when in disagreement. Andrews, Patronage and Poetry, 52.

43. Land bailiff was an estimable job, both in terms of the "manifold and diverse" duties it involved and its (relative) respectability at the top of the servant hierarchy. J. Jean Hecht, The Domestic Servant in Eighteenth-Century England (London, 1976), 38. 
previous incumbent, who had resigned his office. Condemning his "Imprudence for resigning such a situation, without any fairer Prospect," Woodhouse however expressed his "full confidence" in Montagu's sympathy with the "general feelings that actuate the human Breast, in every Rank \& in every Station"- thereby excusing her of any fault in the matter-and added, hypothetically:

If a Man was to be expos'd, in such a Situation, as in a Pillory, to be pelted with Scoffs \& Insults, it would be quite another affair. No Man that was conscious of the dignity of his Nature, \& of the natural, tho' not political, Equality of Mankind, could possibly bear it [...]. But the Case [in question] is quite different. (October 29, [1766], MO 6789)44

Woodhouse supposed that willing service should be met with a master's reciprocal recognition of the worker's equal moral and intellectual "dignity," despite differences in rank or status. His repeated attestation of confidence in Montagu's sensibility, therefore, cloaked what is in fact a statement about the conditions he expected to meet in her employ. "Equality" is a theme that Woodhouse returned to a week later, writing:

I have fresh Reasons to contemplate my Removal with satisfaction, that I may escape some late oppressions of Envy and selfishness; by which I am subjected to Labours \& Payments both ungenerous \& unjust in my present situation. When the poor Man rises towards an Equality with his envious \& ambitious neighbours, they naturally exert their utmost efforts to reduce him to his former despicable depressed level. (November $7,1766, \mathrm{MO} 6786$ )

Woodhouse's social criticism developed to address the class difference of his patrons in particular. On the theme of absences, in early 1767 he "object[ed]" to Montagu's failure to "say something about my good Friend Lord Lyttelton." He then launched into a philosophical complaint concerning Lyttelton's forgetting to send his regards to him, concluding, "Tell him I will not forgive him if the sacred Tie of Friendship is broken by this neglect." "But perhaps I am abusing him for your fault," he reflected, adding, "I know you are both so elevated above my Reach that I shall never engross so much of your attention as I wish." Notwithstanding this frank admission of their elevation, he insisted that those who enjoy the title of "Friend" ought not be excused for neglect, or expect any other exemptions, based on their superior rank:

Mr. Shenstone seems to have thought that Familiarity was inconsistent with Esteem. It may it's true be an Enemy to that slavish Deference that

44. Though this letter, marked "Accepts Steward's Place," is clearly dated October 29, there is no indication of the year. Comparing it against other letters, however, and considering the increasing discussion of Sandleford in letters of late 1766 and throughout 1767, it seems likely that it was written prior to those, in 1766 . 
an imperious Tyrannical Mind would wish to cherish, but [it] is the greatest Encourager of those more generous \& tender Feelings, that a Truly great \& noble soul will think more than compensates for all the servile awe of Reverence that Thousands of cringing slaves could pay. (February 28, 1767, MO 6788)

This oblique statement demonstrates the way in which Woodhouse interwove socially critical and prescriptive opinions into his epistolary correspondence. 45 Despite using highly polemical language, he suggested that his directness was a sign of respect. Emphasizing the universality of "generous \& tender Feelings," he censured the kind of "imperious Tyrannical Mind" that demands "slavish Deference" and exhorted both parties by contrast to take on an equal, outspoken, and hence authentic "Familiarity." 46 No longer apologetic, Woodhouse proudly owned "Familiarity" as a demonstration of his fidelity, a point he reinforced by signing the letter, "in spite of appearances I am not less, dear Madam, your most obedient hum [b]'[e]. Ser[van]t. than [your] affec$\mathrm{t}[\text { iona }]^{\mathrm{t}}[\mathrm{e}]$. Friend J. W." 47 By thus anticipating his patrons' allowance of his boldness, and assuring them that its basis lay in affection, he paid a compliment to their "Truly great \& noble soul[s]." He concluded, "Much more might be said on the subject; but this I said as a Proof that I knew my Lord would forgive me for any innocent Freedoms in Writing \& or Conversation." He was not mistaken, and this unusually candid quality was even respected by his patrons. As Montagu later remarked to her sister, "There is at the same time an honest freedom of soul in Woodhouse which makes him not servile tho humble" (May 11, 1767, MO 5852). Moreover, Woodhouse's complaint may have had the desired effect, as in future Lyttelton made sure to have his "best compliments wait on Mr. Montagu and your Bard; not forgetting the sweet Daphne" (September 3, 1768, MO 1353).

45. Woodhouse's remark offers a subtly different perspective from the professed opinion of Shenstone, that "I have been formerly so silly as to hope, that, every servant I had might be made a friend: I am now convinced that the nature of servitude bears a contrary tendency. [...] it is the nature of servitude to discard all generous motives of obedience; and to point out no other than those scoundrel ones of interest and fear"; William Shenstone, Essays in Men and Manners (London, 1765), 144-45.

46. In this sense Woodhouse could be compared to the black shopkeeper and abolitionist writer Ignatius Sancho (ca. 1729-80) in his fascinating introductory letters to Laurence Sterne. As Helena Woodard argues, by "Lacing bravura with deference, he both anticipates a positive response from Sterne and defuses what might be construed in epistolary etiquette as 'upstart' behaviour"; Helena Woodard, African-British Writings in the Eighteenth Century: The Politics of Race and Reason (London, 1999), 79. See also Markman Ellis, "Ignatius Sancho's Letters: Sentimental Libertinism and the Politics of Form," in Genius in Bondage: Literature of the Early Black Atlantic, ed. Vincent Caretta and Philip Gould (Lexington, Ky., 2001), 199-217. Such "aggressive familiarity" is discussed in depth by Lynne Magnusson in Cultures of Correspondence in Early Modern Britain, ed. James Daybell and Andrew Gordon (Philadelphia, Pa., 2016), 131-55 at 152.

47. My emphasis. Woodhouse often used abbreviations when running out of space at the end of letters. Assuming the clearly identifiable "than" is not a mistake, however, this signature presents a subtle but significant change from his conventional formula of, for instance, "Dear Madam, your most oblig'd most obedient hum[b]le. Ser[van]t. \& affectionate Friend J. Woodhouse" (November 27, 1766, MO 6787). 
Woodhouse had good reason to be grateful to his patrons, whose practical but also personal forms of support vitally enabled him as a poet and allowed him to secure social and economic advantages that would otherwise have been out of his reach. However, this did not make him submissive. Although patronized poets were expected to assume an attitude of deference, Woodhouse's relationship with Lyttelton and Montagu was based on an uncommon degree of frankness. Not only was Woodhouse prepared to stand up to class prejudice when confronted, but through his grasp of epistolary intimacy, he openly and successfully commented on more complex forms of social difference. This egalitarian strain in Woodhouse's letters is remarkable and illustrates the skill with which he was able to combine commendation with critique in his writing - his "Familiarity" preparing the way for an innocent, though not entirely apolitical, "Freedom."

\section{— Pulling His Punches: Woodhouse as a Radical Social Critic in Disguise}

Having outlined how Woodhouse's embryonic egalitarian views manifested themselves in his life and letters, we can pursue a more thorough reassessment of his early poetry. Before this, however, it serves to pay some attention to the circumstances in which Woodhouse's collected poetry originally appeared in print. In recent years scholarship has focused attention on the significance of paratexts - the additional materials surrounding the main text of published works, such as titles, forewords, epigraphs, illustrations, footnotes, and postscripts-as conditioning an author's reception. Defined by Gérard Genette as a "threshold," the paratext is "a privileged place of a pragmatics and a strategy, of an influence on the public, an influence that [...] is at the service of a better reception for the text and a more pertinent reading of it." 48 No less so now than in his own day, Woodhouse's reputation has been overwhelmingly determined by the paratextual material that introduces his poetry, and over which it seems he had little control. While both prefatory and poetic texts have contributed, in varying ways, to the characterization of the early Woodhouse as a complaisant and sycophantic object of patronage, new evidence significantly complicates this picture. As I argue, Woodhouse's immediate response to the "Advertisement" to Poems on Sundry Occasions speaks against this particular paratext; moreover, the poetry within pursues a radical rethinking of the traditional dynamics of upper-class patronage.

The authoritative, editorial introduction to Poems on Sundry Occasions naturally set the terms of Woodhouse's public reception. Occupying the first five pages of the work, the "Advertisement" offers "some Account of an Author who was never heard of before" and describes Woodhouse's miraculous rise to notice through his acquaintance with the "late ingenious Mr. Shenstone." Begging pardon for any intrusion upon the "benevolent Reader," the editor then proposes to give an indication of "the Author's education, and present situation." He characterizes the "obscure Poet" as "an honest, sober, industrious Man" who-though an avid autodidact and writerdutifully applies himself to his wonted occupations. In this way, the editor signaled 
that Woodhouse did not possess any ideas above his "Station and Circumstances," and thus promoted this "uncommon genius" to the polite reader as an "Object worthy of his Notice." 49 As William Christmas states, "in the context of prevailing cultural attitudes about work and writing for plebeian upstarts such as Woodhouse, this portrait amounts to good advertising."50

This "Advertisement" shaped Woodhouse's reception more than most introductions of laboring-class writers in the period. The earliest review of Poems on Sundry Occasions appeared in a "triweekly evening paper," the St. James's Chronicle, on April 26, 1764 , and, as its subheading clearly states, was a word-for-word copy of the "Advertisement." 51 While this might explain why the St. James's Chronicle has not yet been cited in scholarly discussions of Woodhouse's reception, it was the first of many newspapers and magazines that simply reused the "Advertisement" in place of an original review. Phrased as an account of "a gentleman, who was honoured with the late ingenious Mr. Shenstone's Correspondence, [and who] has undertaken to inform the Reader, [of] James Woodhouse," the "Advertisement" assumed the form of an open letter and thus lent itself (perhaps as intended) to rapid reproduction in the periodical press. 52 Shorter, excerpted versions of the "Advertisement" appeared on the same day in competing newspapers, and in subsequent years the text of the "Advertisement" was repeatedly reproduced and readapted, eventually with no acknowledgment whatsoever. 53

If the St. James's Chronicle marked the beginning of this influential trend, its pages soon featured an important counter-narrative to the "Advertisement," one that critics have not yet noticed. The following issue arrived just two days later and contained an animated letter "To the Printer of the St. James's Chronicle." It begins astutely: "Sir, I have seen in your Paper the Preface to Poems by a Journeyman Shoemaker, and have also perused several of the Poems themselves with a singular Pleasure,

49. Woodhouse, Poems on Sundry Occasions, iii-vii.

50. Christmas, Lab'ring Muses, 188.

51. St. James's Chronicle or the British Evening Post 490 (April 26, 1764). Richmond P. Bond and Marjorie N. Bond, “The Minute Books of the St. James's Chronicle," Studies in Bibliography 28 (1975): $17-40$ at 17 .

52. The "Advertisement" was likely written by Shenstone's former publisher, Robert Dodsley (1704-1764). Earlier in the century, Dodsley had himself enjoyed success as a plebeian poet, writing Servitude: A Poem (1729) and The Muse in Livery: Or, The Footman's Miscellany (1732) before opening a bookshop in Pall Mall with the proceeds—and $£ 100$ from Alexander Pope. He subsequently became one of the most prominent publishers in the eighteenth century and also presided over a number of periodicals. See Harry M. Solomon, The Rise of Robert Dodsley: Creating the New Age of Print (Carbondale, Ill., 1996).

53. The London Chronicle 1147 (April 26, 1764), The Public Advertiser 9201 (April 26, 1764). See also The General Magazine of Arts and Sciences, April 1764, 198, which quotes from the "Advertisement" and identifies Robert Dodsley as its author. The enduring image that the "Advertisement" provided of Woodhouse-who "sits at his Work with a Pen and Ink by him, and when he has made a Couplet he writes them down on his Knee"-subsequently became the basis for his portrait, published initially in the Museum and Complete Magazine, February 1765, 97-98. Woodhouse neither sat for this picture nor authorized it. As he wrote in Crispinus Scriblerus, upon first coming across it in shop windows in London, he felt the "awkward sketch [...] / [...] never mark'd his character at all" (chap. 4, lines 510-16). The text of the "Advertisement" and the illustration of Woodhouse are reproduced in an article entitled "Anecdotes of James Woodhouse" in The Oxford Magazine 10 (1773): 454-56. 
though I must own with less Surprize than the Generality of his Readers.” Admitting that "Stephen Duck, The Thresher" and "[Henry] Jones, the Bricklayer" (1721-1770) were "somewhat extraordinary" in leaving their occupations to pursue writing professionally, the writer, however, argues that the combination of work and writing is "not [... ] altogether so miraculous" for a shoemaker. He states that there is "a very strict Analogy between Verse-making and Shoemaking," citing the compatibility of this sedentary trade to oral recitation and thus poetic composition. Developing this analogy, he plays on the association of physical and poetic "feet," and suggests that different types of shoe correspond to different types of genre. For example, "Pindarick Odes, which are often on Equestrian Subjects, may be dispatched with Spatterdashes; light, airy Verses with Pumps; and all easy, careless, gentlemanlike Compositions with Slippers." As Keegan observes, these are "puns frequently present in shoemaker poetry" and "suggest a linguistic link for the affinity between shoemakers and poets." 54 This humorous tone, however, turns to seriousness at the letter's conclusion, which condemns the exclusionary practices of "Scholars [...] who want to engross all the Provinces of Literature, [and] do not care that any body should write but themselves." Rejecting assumptions about the exceptionality of shoemaker poets and, by association, distinctions between mental and manual labor, the writer reasons against the prevailing prejudices that restricted working people's participation in literary culture:

Verse-making is in the present Age, generally speaking, as mechanical as Shoe-making. Why then should not a poor Mechanick shew his Industry both ways, especially a Shoe-maker, whose Profession, as I have endeavoured to shew, is so consistent with that of a Poet, and who can write Verses without neglecting his other Business, or rendering himself liable to the Censure contained in the old Adage of ne sutor ultrà crepidam. 55

Signed "Crispinus Scriblerus," the letter was almost certainly penned by James Woodhouse. "Crispinus" was a common moniker for shoemaker poets-alluding to St. Crispin, the patron saint of shoemakers; yet its pairing with the even more fashionable "Scriblerus"-evoking the collective satire "The Memoirs of Martinus Scriblerus" written by Pope, Swift, and others in 1714-was entirely original to Woodhouse. ${ }^{66}$ This pseudonym together with variations on the Latin proverb "ne sutor ultrà crepidam" ("let not the shoemaker judge beyond his last") would feature repeatedly in Woodhouse's later works. The proverb derives from Pliny the Elder's story of Apelles's

54. Bridget Keegan, “Cobbling Verse: Shoemaker Poets of the Long Eighteenth Century," Eighteenth Century: Theory and Interpretation 42, no. 3 (2001): 195-217 at 205.

55. St. James's Chronicle or the British Evening Post 491 (April 28, 1764). A curiosity, this letter was reprinted among a collection of letters “To the Printer of the St. James's Chronicle," in George Colman, Prose on Several Occasions: Accompanied with Some Pieces in Verse, 2 vols. (London, 1787), 2:47-49.

56. Christmas, Lab'ring Muses, 199. Despite being composed throughout the 179os, Woodhouse's Crispinus Scriblerus finds no mention in Ashley Marshall's list of "thirty-two works signed by 'Scriblerus' (or some version thereof) between 1731 and the end of the century"; "The Myth of Scriblerus," Journal for Eighteenth-Century Studies 31, no. 1 (2008): 77-99 at 86. 
outrage at a shoemaker's pointing out a blemish on one of his paintings and warned plebeians not to comment on matters outside of their sphere. 57 Woodhouse had himself experienced this kind of double-edged advice, not least in his 1764 meeting with Samuel Johnson..$^{8}$ Woodhouse, however, reversed the maxim, removing the negative "ne," in order to reclaim it as a powerful rallying cry; the altered motto appears prominently on the title page of Crispinus Scriblerus. 59 Evidently, these calling cards, which were central to Woodhouse's outspoken authorial persona after 1788 , were just as important to the argument of this letter of 1764 . We might read this reply to the St. James's Chronicle as opportunism, a cynical attempt to promote his debut work, but it seems more likely that Woodhouse simply disagreed with his presentation as a charity-worthy curiosity in the text of the "Advertisement" and sought to correct it-even as, paradoxically, he relied upon a "humble" public persona in order to be accepted by polite audiences. ${ }^{60}$ As E. P. Thompson writes of the "anonymous tradition" of plebeian protest in this period, "the anonymous threat, or individual terrorist act, is often found in a society of total clientage or dependency, the other side of the medal of simulated deference." 61 Just as in his autobiography, therefore, the pseudonym "Crispinus Scriblerus" allowed Woodhouse to shield his identity while facilitating open criticism.

Woodhouse's pseudonymous letter to the St. James's Chronicle prompts us to reconsider his portrayal as an object of patronage who presented himself, or allowed himself to be presented, in a position of absolute clientage. As grateful as he was toward his patrons, the requirements of the literary marketplace grated on his strong sense of

57. Pliny the Elder, Natural History, trans. H. Rackham, 10 vols. (Cambridge, Mass., 1952), 9:322-25. Pliny's version was translated into English by Philemon Holland in 1601. Samuel Johnson mentions the story of the shoemaker in Rambler 4 (March 31, 1750).

58. Woodhouse met Johnson in London in early 1764, at a dinner hosted by Hester Lynch Thrale. Johnson apparently advised Woodhouse to "Give nights and days, Sir [...] to the study of Addison, if you mean either to be a good writer, or, what is more worth, an honest man"; Johnsonian Miscellanies, ed. George B. Hill, 2 vols. (Oxford, 1897), 1:233. Johnson subsequently dismissed Woodhouse, however, announcing, "He may make an excellent shoemaker, but can never make a good poet"; James Boswell, Boswell's Life of Johnson, ed. George B. Hill, 6 vols. (Oxford, 1934), 2:127. Woodhouse later recalled that "Dr Johnson's curiosity was excited by what was said of me in the literary world, as a kind of wild beast from the country"; William Mudford, "Sorting my Letters and Papers," Blackwood's Magazine 26 (1829): 748-55 at 754 .

59. This rallying cry appears, for instance, as the subtitle to the poem "Ridicule" in the 1788 Poems on Several Occasions; it also appears on the title page of Norbury Park, A Poem; with Several Others, Written on Various Occasions (1803) and, in the same volume, as an epigraph to "Epistle, to Shenstone, in the Shades; On Reading his Rural Elegance. Written in 1784."

6o. Such "fictional stand-ins" in periodicals served as a means of participating in debates about authorship from a more "impartial" and "literary" standpoint. It is interesting, though not altogether surprising, to see that laboring-class writers were also using these fictional identities to good effect. See Manushag N. Powell, Performing Authorship in Eighteenth-Century English Periodicals (Lanham, Md., 2012), 4.

61. E. P. Thompson, “Patrician Society, Plebeian Culture," Journal of Social History 7, no. 4 (1974): $382-405$ at 399 . 
dignity as a poet who had always continued writing alongside work and who believed that this in no way made his admittance into the "Provinces of Literature" a matter for apology. ${ }^{62}$ Acknowledging the expediency of his portrayal in the "Advertisement," however, Woodhouse avoided completely controverting it. Indeed, the early invention of the pseudonym "Crispinus Scriblerus" suggests Woodhouse's awareness of the incongruity of his outspoken views with the polite cultural expectations that he had to navigate in order to succeed as a plebeian poet. In the final section of this essay, I explore how Woodhouse channeled his egalitarian attitudes, and specifically his concerns about the contemporary perception of patronage as inducing artistic self-abasement and venality, into the more complex territory of his published poetry.

Aside from the influence of paratexts, it is not difficult to understand why the gratitude Woodhouse professes in his poetry has so often been read as sycophancy. Given that he addressed all but two of the compositions in Poems on Several Occasions directly to patrons and further adorned them with titles such as "Benevolence" and "Gratitude," Woodhouse can hardly be said to have reneged on the tacit agreement that poets formally recognize their patrons. As Paul Magnuson states, these prefatory and poetic tributes are all "public forms" through which "the social or political relationship of author to patron, opponent, or friend is implied." 63 What becomes clear upon a careful reassessment of Woodhouse's early poetry, however, is that the very public forms that he chose-verse epistles, topographical poems, elegies, and odes-allowed him to radically intervene in contemporary discussions about the social and political nature of patronage.

If in his pastoral poetry "the imitation of generic repertoire enabled, rather than restricted, [his] inventive impulses," I contend that Woodhouse's investment in the "high culture poetics of politeness [...] as an alien" was itself a means through which he "consciously negotiate[d] and interrogate[d] the division between classes." 64 To perceive this, we need to pay closer attention to how Woodhouse envisioned himself as an object of patronage and, in turn, patronage as an object of praise. In his earliest poetic addresses Woodhouse established an assertive, dignified tone and explicitly rejected assumptions about the venality of writing under patronage. Adopting an evangelical perspective upon worldly wealth, he insisted instead that charitable assistance was a spiritual duty and moral good, premised upon the inviolable value of all persons regardless of rank. Likewise in the public odes, "Benevolence" and "Gratitude," Woodhouse's engagement with the tradition of thanksgiving was shaped by his radical

62. In Poems on Several Occasions (1766), Woodhouse pens his own preface, "The Author's Apology," which is placed before the original 1764 "Advertisement." Subtly refuting the notion that his "useful" activities are restricted to his manual employments, Woodhouse writes, "I am much obliged to many of my unknown Benefactors for their apprehensions, least my unexpected success should so far elate me, as to make me a useless member of the community; but I hope, by my conduct, to convince them that such apprehensions were groundless; for if I have the least knowledge of myself, [...] I shall think myself indebted to the divine Providence, and strive to shew my gratitude to the public by endeavouring all in my narrow sphere to promote virtue in general"' (vii-viii).

63. Paul Magnuson, Reading Public Romanticism (Princeton, N.J., 1998), 46.

64. Jung, "Shenstone, Woodhouse, and Mid-Eighteenth-Century Poetics," 144, 129. 
Christian egalitarianism. His language of compliment was not sycophancy, but a wellweighed and conditional form of praise: while commending his patrons' generosity, he criticized others who, by contrast, sought only to promote their own interests. Much as in his personal letters, therefore, it was through the rhetoric of praise that Woodhouse modulated his critical views into an acceptable, even purposeful, public form.

Woodhouse's early poetry reimagines the kind of relationship that can exist between people of different ranks. Immediately following the "Advertisement" to Poems on Sundry Occasions, "An Elegy to William Shenstone" offers a subtly different representation of his admittance into the realms of poetry. Woodhouse had originally sent this verse epistle to Shenstone in 1759 specifically to regain admittance to the Leasowes following its closure, but he was likely aware of the other implications of this act. When Johnson waited in Lord Chesterfield's "outward rooms" in hopes of securing support for his dictionary project ten years earlier, he was following the standard means of courting patronage: an introduction followed by a direct appeal, whether in person or by letter. ${ }^{65}$ While Woodhouse acknowledges his lowly status, begging Shenstone's "Pardon" for his "intruding strain, / [. . ] the boldness of a village swain" (lines 1-2), he however stresses the unconventionality of his appeal, declaring: "Think not I write for hire!-My gen'rous muse / Has no such mean, such mercenary views!” (lines 101-2).

Not a platitude, this rejection of "hire" underpins Woodhouse's progressive plebeian philosophy. Sycophancy was as much a preoccupation of Woodhouse's own period as it is among his critics today. Despite his early suit to Chesterfield, Johnson was at the forefront of an influential backlash against patronage that escalated in the mid-century; he wrote in 1751, "To solicit patronage is, at least, in the event, to set virtue to sale. None can be pleased without praise, and few can be praised without falsehood; few can be assiduous without servility, and none can be servile without corruption." 66 By forestalling accusations such as these, Woodhouse's appeal conceives of the possibility of more disinterested relationships between those of different ranks. Desiring only his "mind's improvement" (line 106), Woodhouse begs admittance to Shenstone's gardens and, more significantly, his society: he introduces himself as one seeking not so much patronage as friendship. Several critics have considered the political implications of Woodhouse's polite cultivations and his garden poetry in particular as activities that "rank[ed] the peasant equal with the peer" (line 123). However, the forging of communities across class boundaries performed a similar, if not more tangible, role in challenging social distinctions. As Van-Hagen states in his excellent discussion

65. Samuel Johnson, The Letters of Samuel Johnson: The Hyde Edition, ed. Bruce Redford, 5 vols. (Oxford, 1992-94), 1:95.

66. Johnson, Rambler 104 (March 16, 1751). While criticizing patronage in principle, Johnson was also motivated by the perceived danger that parvenus like Woodhouse presented to the literary profession. Boswell recalls that "He spoke with much contempt of the notice taken of Woodhouse, the poetical shoemaker. He said, it was all vanity and childishness; and that such objects were, to those who patronised them, mere mirrours of their own superiority" - the corollary being that patronage debased a writer's art, forcing him to "say what pleases his patron [...] whether that be truth or falsehood"; Boswell, Life of Johnson, 2:127, 5:59. 
of Crispinus Scriblerus, "For Woodhouse, true sociability, just like landscape appreciation, levels disparities of wealth and/or rank." 67 This observation can also be extended to Woodhouse's conception of benevolence in his early poetry.

Woodhouse phrases his request as a "humble claim" (line 124), but an important eighteenth-century signification of the word claim was "To demand of right; to require authoritatively; not to beg or accept as favour, but to exact as due." 68 Thus Woodhouse layers his application to Shenstone with self-assertion. Addressing him in the third person, he asks rhetorically:

Shall he, benevolent as wise, disdain

The muse's suitor, tho' a sandal'd swain?

Tho' no auspicious rent-rolls grace my line,

I boast the same original divine.

(Lines 13-16)

Far from servile, Woodhouse exalts but also exhorts Shenstone's generosity with an air of equality. As a reviewer in the Gentleman's Magazine remarked of these lines, "tho' in the character of a suitor, and with a proper sense of the inferiority of his station, yet there is a consciousness of that equality of nature, which petitioners and dedicators too often prostitute or forget." 69 Moreover, these lines anticipate Woodhouse's subsequent emphasis upon "the natural, tho' not political, Equality of Mankind," an equality implanted within God's creation, but deviated from after the Fall. In accordance with this view, Woodhouse conceived of benevolence broadly as a means of elevating the condition of others materially and socially, hence repairing unjust inequalities. ${ }^{70}$ As he later stated, "Nothing is more repugnant, more disagreeable to my Mind, than Refusal, or denial; when the Object of the Petition is strictly virtuous" (May 30, 1766, MO 6784). Hence the noticeable firmness of his claim in the "Elegy." "Is this my prayer?," he asks. "It must acceptance find; / My muse not venal; thine humane and kind" (lines 110-11).

\section{额}

As Woodhouse writes in "Elegy II," thanking Shenstone for granting his request, his "rude, presumptuous muse, uncheck'd" was "More favour'd than she could expect" (lines 1-2). Although poets frequently employed the antiflattery topos in an attempt to authenticate their thanks, this vindication of gratitude (and hence praise) has an additional, functional role for Woodhouse. As participatory, public act, it is precisely

67. Van-Hagen, "Patrons, Influences, and Poetic Communities," 321.

68. Johnson, Dictionary.

69. Gentleman's Magazine 34 (June 1764), 289.

70. For David Hartley, author of the 1749 philosophical work Observations on Man, His Frame, His Duty, and His Expectations, "the final effacement of difference which is a goal and the imperative of benevolence is found when 'all become members of the mystical body of Christ'” (477). 
through gratitude that he can critically appraise benevolence according to his egalitarian views; in short, his gratitude not only serves to commend but also to recommend certain types of behavior productive of social good. This aspect of Woodhouse's poetry is best understood in the context of epideictic oratory, a rhetorical mode that seeks to educate the public. ${ }^{71}$ Its more modern counterpart, the panegyric, was a form of congratulatory praise that idealized public figures as tangible models for imitation. Far from simple flattery, therefore, the panegyric was defined by practitioners such as Erasmus as a means of "exhorting to virtue under pretext of praise." 72 While the panegyric had fallen out of fashion by Woodhouse's time, more often being approached as a mock genre, this did not mean that the moral function of praise in literature was unrecognized. 73 Such a sensitivity is pronounced in Woodhouse's assessment of Elizabeth Carter's Epictetus (1758):

If she translated it for the sake of pecuniary profit I have thank'd her enough already; if she did it for the sake of fame I would add praise to my thanks; if she wrote for the good of the public I cannot thank or praise her enough. (November 28, 1768, MO 6792)

Woodhouse's combination of praise and blame enhances the efficacy of his own writing as a means of moral improvement, and it also allows for the inscription of his egalitarian social views. Although scholarship has tended to interpret laboring-class writers' responses to patronage as either sycophantic or rebellious-with little appreciation of the possibilities between these two extremes-one example highlights the actual license that marginal writers could gain by participating, as outsiders, in customary forms of politeness. 74 Mary Leapor (1722-1746), the Northamptonshire kitchenmaid, became one of the most prominent plebeian poets of the mid-century, albeit posthumously. Despite her premature death, her circle of supporters ensured that her works were published, in two volumes, in 1748 and 1751. In the earlier of her

71. Gerard A. Hauser, “Aristotle on Epideictic: The Formation of Public Morality," Rhetoric Society Quarterly 29, no.1(1999): 5-23 at 10.

72. James Garrison, Dryden and the Tradition of the Panegyric (Berkeley, Calif., 1975), 21. For a lengthier study of the advisory and critical aspect of formal praise, see Kevin Sharpe, Criticism and Compliment: The Politics of Literature in the England of Charles I (Cambridge, 1987).

73. Jon Thomas Rowland, Faint Praise and Civil Leer: The "Decline" of Eighteenth-Century Panegyric (London, 1994). In an issue devoted to the subject, Johnson states, "To scatter praise or blame without regard to justice, is to destroy the distinction of good and evil" while "To encourage merit with praise is the great business of literature"; Johnson, Rambler 136 (July 16, 1751). See also Johnson, Adventurer 137 (February 26, 1754).

74. Tim Burke regrets this "rather familiar" view that "envisages the labouring-class poet as striking two poses only. The first [...] involves the author clinging, gratefully, to the coat-tails of high culture [...]. The second conceives of the author employing satire, parody or revision to subvert texts or genres which exclude matters of concern to the labouring classes"; introduction to Eighteenth-Century English Labouring-Class Poetry, vol. 3, 1780-180o, ed. Tim Burke (London, 2003), xvii-xxxiv at xxvii. That laboring-class poets, conscious of the cultural codes they were expected to conform to, might occupy differing and apparently contradictory stances seems demonstrable in the case of Woodhouse. 
two "Mira to Octavia" poems, in which she (an "officious Friend") sets out to advise the young lady she serves against an unsuitable choice of husband, she writes:

You think your Conduct merits only Praise,

But out-law'd Poets censure whom they please:75

This elliptical couplet has been read as an apology for the outspokenness of "poets [who] operate outside the bounds of social graces," but it can also be read as a statement about the connection between "censure" and "Praise." 76 While Leapor could mean that "out-law'd Poets censure whom[ever] they please" (i.e., capriciously), the preceding line makes possible the reading that "out-law'd Poets censure [those] whom they please [with Praise]," suggesting that censure is itself a function of praise. Indeed, in the second poem Leapor redirects her attention from Octavia-since placed "Above my Censure, and beyond my Praise" - to a critique of marriage conventions more broadly. 77 While Caryn Chaden notes that Leapor "claims the right to criticise her social superiors" in this poem specifically as a result of her outsider status, it remains equally possible that a creative investment in the conventions of polite social interaction, such as compliment, was a means of subverting class distinctions altogether. ${ }^{78}$

Understanding how plebeian poets adapted established literary genres and discourses to their own expressive purposes is vital to recovering not only the politics of Woodhouse's early poetry but also its sophistication, complexity, and breadth of reference. Simply put, Woodhouse's gratitude to patrons comprises active moral and social criticism: he praises benevolence for recognizing the equal worth of the poor and blames other, more acquisitive uses of wealth for their hierarchical dimensions. In his two public odes, "Benevolence" and "Gratitude," Woodhouse enters into an ongoing eighteenth-century debate about the proper stewardship of wealth, directly responding to the argument of Alexander Pope's "Epistle to Burlington, Of the Use of Riches" (1735). Discussing Woodhouse's sustained "ambivalence towards Pope" in Crispinus Scriblerus, Van-Hagen claims that he "employs an obviously Popean satire, while nonetheless articulating a political and theological philosophy completely at odds with the Bard of Twickenham's."79 Although less conspicuous in these public odes, Woodhouse's early engagement with Pope demonstrates a comparable ambivalence: while emulating Pope's distinctive version of the formal verse epistle-addressed to elevated social figures and treating important moral topics-he also instigates his individual and class-conscious response to Pope's conservative politics and apologetics.

"Benevolence, An Ode" is a compressed poem occasioned by Woodhouse's first receiving financial support for his writing. Subtitled "Inscribed to my Friends," its edi-

75. Mary Leapor, Poems on Several Occasions, 2 vols. (London, 1748 and 1751), 1:258-61, lines 2-4. 76. Caryn Chaden, "Mentored from the Page: Mary Leapor's Relationship with Alexander Pope," in Pope, Swift, and Women Writers, ed. Donald C. Mell (Newark, N.J., 1996), 31-47 at 38.

77. Leapor, Poems, 2:100-110, line 11.

78. Chaden, "Mentored from the Page," 39.

79. Van-Hagen, "Patrons, Influences, and Poetic Communities," 330. 
torial note explains that "His two first elegies being seen by some gentlemen and ladies in London in manuscript, they made a small subscription for him." Thanking these friends' generosity by contrasting it with other, fashionable (mis)uses of wealth, Woodhouse commends benevolence while criticizing attitudes common among the socially privileged. The first line, "Let others boast Palladian skill," instantly indicates his debt to Pope's "Epistle to Burlington." Distinguishing the third Earl of Burlington, Richard Boyle (1694-1753), and his neo-Palladian architectural designs from an extravagant and fame-seeking "Timon," Pope had satirized fashionable pretenders to taste- "Imitating Fools" who only "act a true Palladian part." 80 Pope's approbation of Burlington's magnificence is based upon the principle that "Taste" should be informed above all by "Use" and thus that estate owners should show due moderation in their improvements. ${ }^{81}$ The evolving half-titles of the poem indicate its dual emphasis: originally "OfTaste" (1731), then "Of False Taste" (1731/32), and finally "Of the Use of Riches" in Moral Essays (1735). Despite these titular adjustments, the poem remains fundamentally concerned with good spending, not giving-effectively perceiving the former as doing the job of the latter. Inveighing against the "false Taste of Magnificence" in architecture, landscape gardening, and finally domestic arrangements at "Timon's Villa," Pope's description of Timon's quixotic feast concludes with this qualification:

Yet hence the Poor are cloath'd, the Hungry fed;

Health to himself, and to his Infants bread

The Lab'rer bears; What his hard heart denies, His charitable Vanity supplies. ${ }^{82}$

In this Mandevillian expression of the public benefit of private vices, or "trickle-down" economics, the egoistic use of riches is accorded an indirect charitable effect. Pope ironically observes that by employing workers to satisfy his extravagant tastes, Timon's wealth is justly diffused to the needy. Leapor's witty "Crumble-Hall" has been convincingly interpreted as a complete rewriting of Pope's "Epistle to Burlington" that "effectively turns his satiric mode into a significant ideological critique of the productive social relations which support the existence of elaborate country houses and their families." 83 In "Benevolence, An Ode," Woodhouse similarly rejects Pope's elite apologetics, although in a more matter-of-fact and moralizing manner. As a rural shoemaker with a keen awareness of the ravages of poverty, Woodhouse formed a quite different notion of "use" and "taste" that saw helping others as a public duty diametrically opposed to more

80. Alexander Pope, "Epistle to Burlington, Of the Use of Riches," The Twickenham Edition of the Poems of Alexander Pope, gen. ed. John Butt, vol. 3, pt. 2, Epistles to Several Persons (Moral Essays), ed. F. W. Bateson (London and New Haven, Conn., 1951), 130-51, lines 23-38.

81. Erik Bond, Speculation and Imaginative Government in Eighteenth-Century Literature (Columbus, Ohio, 2007), 113-14.

82. Pope, "Epistle to Burlington," lines 99, 169-72.

83. Christmas, The Lab'ring Muses, 173. For a more in-depth account of Pope's social politics, see John Morillo, "Benevolence and the Social Order in Pope" in Uneasy Feelings: Literature, the Passions, and Class from Neoclassicism to Romanticism (New York, 2001), 98-128. 
conspicuous forms of consumption. ${ }^{84}$ Thus, while the only "suff'ring" Pope represents is aesthetic-that of the "eye inverted Nature sees"-Woodhouse questions the very validity of those "charms the gazing eye may fire" when 85

lords, like statues cold,

Devoid of sympathy, behold

Fair worth with penury depress'd

Or indigence expire;

Nor ever know the noblest use of gold.

(“Benevolence," lines 19-24)

Woodhouse refutes Pope's optimism, censuring rather than excusing a culture in which the price of polite refinement-whether gauche or graceful-is the willful deprivation of others. In opposition to Pope's socioeconomic sophistry, where bad taste is justified in terms of its accidental social use, Woodhouse maintains that the "more applausive taste" is not "spending wealth, / In gorgeous waste" (lines 29-31); instead taste should with "BENEvOLENCE combine / To humanize the mind!" (lines 15-16). In accordance with his egalitarian principles, Woodhouse recommends redirecting spiritually and morally burdensome riches to help the poor. The charitable support Woodhouse received from his patrons undoubtedly enabled his poetry; likewise the poem "Benevolence" imagines-in an absolute inversion of Pope's "trickle-down" approach — an ethically and aesthetically improved society from the ground up. ${ }^{86}$

Woodhouse's use of praise as an occasion to express moral and social criticism becomes more sharply defined in the later and much longer poem, "Gratitude." After commending his foremost patrons-Montagu, and Lords Bath, Lyttelton, and Dudleyhe recapitulates his praise in this compressed verse paragraph:

With equal honours, claiming equal praise, A noble train demand my thankful lays; That deign'd to hear me chaunt my mournful airs, While balmy gifts asswag'd my wounding cares; Worth, godlike worth! must in their bosoms dwell, Whose rays of goodness chear the rural cell: Inferior minds the syren pleasure seek, And shun the throbbing breast, the humid cheek,

84. With poor harvests and high prices, on top of mounting antagonisms between social classes, the 1760 s was a notably bad period for the English commoner, resulting in widespread hunger riots, particularly in the crisis year of 1766; Walter J. Shelton, English Hunger and Industrial Disorders: A Study of Social Conflict during the First Decade of George III's Reign (London, 1973), 2, 25-26, 51-67. 85. Pope, "Epistle to Burlington," line 119.

86. During his seventeen-year employment under Montagu, however, Woodhouse would develop a range of more critical views on the misuse of charity as a form of public self-promotion and paternalistic social control. See Peter Denney, “'Unpleasant, tho' Arcadian Spots': Plebeian Poetry, Polite Culture, and the Sentimental Economy of the Landscape Park," Criticism 47, no. 4 (2005): 493-514 at 509. 
While squand'ring wealth, in idle, useless, toys,

Mischievous frolics, or delusive joys,

See want and mis'ry haunt the gloomy cot,

Nor fancy swains deserve a better lot.

(“Gratitude," lines 87-98)

The passage slips seamlessly from praising aristocratic benevolence to critiquing aristocratic abuses of wealth. These abuses, Woodhouse suggests, arise not just from indifference to "want and mis'ry" - a lack of sympathy_but also from the fundamental exclusionary attitude of class supremacy. This was an attitude that had instigated, as Woodhouse was well aware, both the attempts by "Scholars" to prohibit laboringclass writers from the "Provinces of Literature" and, more pertinently, his own peremptory and physically violent expulsion from the Leasowes by Captain Turnpenny.

The early emergence of Woodhouse's radical evangelical views is not altogether surprising given the influence of Methodism in mid-century Shropshire. Developed out of the teachings and tireless lay-preaching of the Anglican clerics John Wesley (17031791) and George Whitefield (1714-1770), by 1767 the Methodist movement included some 24,000 converts, a number that would triple by the end of the century. 87 With its anti-authoritarian ethos and focus on personal discipline and self-improvement, Methodism had significant sociopolitical dimensions; it was particularly popular among artisans and provided an important stimulus to proletarian thinking and organization. ${ }^{88}$ Perceiving this as the catalyst for his political outspokenness, Christmas emphasizes the importance of Woodhouse's "Methodist beliefs late in life," and conjectures that he must have been attracted to them "during his years of service to the Montagus." 99 The poems "Benevolence" and "Gratitude," however, suggest that Methodist principles may have been influencing Woodhouse from a much earlier point. Methodism spread rapidly in the Black Country in the mid-eighteenth century. Wesley began preaching to large congregations in Birmingham from 1743, and in the early 1760 s his visits extended to the wider Shropshire area, which by 1765 had become an established part of the Methodist circuit. $9^{\circ}$ One of Wesley's most influential sermons, "The Use of Money" (1760), encouraged a practical, antimaterialist view on wealth. He advocated industry and frugality and recommended giving all superfluous money away to those in need: not only would this relieve the suffering of the poor and

87. Roy Porter, English Society in the Eighteenth Century (London, 1982), 193.

88. David Hempton, Methodism and Politics in British Society 1750-1850 (London, 1984), 12.

89. Christmas, Lab'ring Muses, 187, 203-4. See also Van-Hagen, "The Life, Works and Reception," 385.

90. W. C. Sheldon, Early Methodism in Birmingham: A Historical Sketch (Birmingham, U.K., 1903), 5-27; R. F. Skinner, Nonconformity in Shropshire, 1662-1816: A Study in the Rise and Progress of Baptist, Congregational, Presbyterian, Quaker and Methodist Societies (Shrewsbury, U.K., 1964), 57. The leader of the American Methodist movement, Francis Asbury (1745-1816), grew up in Shropshire. See John Wigger, American Saint: Francis Asbury and the Methodists (Oxford, 2009), 16-32. 
improve their worldly state, but it would also prevent one's own moral degeneracy. ${ }^{91}$ Whether or not Woodhouse had heard this particular sermon in the 176os, it is remarkable that his poetry points toward a similarly revivalist and socially progressive conclusion.

Citing Pope's “orthodox Christian vision of the world," Aubrey Williams has argued that his controversial excuse for extravagance was not so much a justification of economic self-interest as a theodicean defense of God in light of economic inequity. 92 As Pope himself notes of the "charitable Vanity" passage (quoted above): "The Moral of the whole, where PROVIDENCE is justified in giving Wealth to those who squander it in this manner. A bad Taste employs more hands, and diffuses Expence more than a good one."93 Unlike Pope's individualist-consequentialist approach, Woodhouse is more exacting and insists that intention makes the difference between the good and evil use of riches: only the desire to benefit and elevate others can be considered a morally praiseworthy use of riches. This is in keeping with the Wesleyan idea of men as mere stewards of God's wealth, tasked with the responsibility of using it for good works. While his patrons' generosity bespeaks "Worth, godlike worth!" therefore, Woodhouse's ultimate thanks—his "endless praise"—is addressed to the "Almighty Sire [...] / From [whose] stupendous love all blessings flow, / That sweeten life, or blunt the edge of woe" ("Gratitude," lines 186, 154-56).94 Instead of assuming providence would simply counteract self-interest, therefore, Woodhouse exhorts a more active redistribution of wealth as a socially and spiritually beneficial act, in accordance with a more literal reading of Christian charity. As he later envisions in his autobiography:

\author{
A moral Government-where none could claim \\ Unequal Wealth, or Influence, Pomp or Fame: \\ But each, submitting to His kingly call \\ Was eager to distribute helps to all. \\ Superior stood His intellectual Code, \\ A perfect Plan, brought from His first Abode; \\ Where Thanks and Praise, in act, or word, or thought, \\ All center'd in the Saviour, where they ought-
}

(Crispinus Scriblerus, chap. 16, lines 1157-64)

91. For an interesting discussion of this sermon's significance, see Misty G. Anderson, Imagining Methodism in Eighteenth-Century Britain: Enthusiasm, Belief, and the Borders of the Self(Baltimore, 2012), 20-21.

92. Aubrey L. Williams, “A Hell for 'Ears Polite’: Pope’s Epistle to Burlington,” English Literary History 51, no. 3 (1984): 479-503 at 485 .

93. This note appeared in Pope's edited version of the poem from 1735 onwards; Pope, Epistles to Several Persons (Moral Essays), ed. Bateson, 125. Pope's capitalization of "PROVIDENCE" here is echoed, perhaps purposefully, in Woodhouse's contrasting emphasis upon "BENEVOLENCE" in his poem of the same title.

94. This structure and sentiment is repeated in the "Author's Apology" to Poems on Several Occasions (1766). Following his thanks to his patrons, Woodhouse adds, "whatever good fortune happens to me, or additional blessings I enjoy, I shall think myself indebted to the divine Providence" (vii-viii). 
It is because benevolence fulfills a divine function, helping to redress the arbitrary material differences between men in a postlapsarian state, that Woodhouse awards such "Thanks and Praise" to his patrons in his early poetry. By reconfiguring patronage as a moral relationship, Woodhouse not only defends this traditional literary institution from cynicism but also projects in his poetry a vision of improved social relations. If Poems on Several Occasions appears to typify what critics have thought of as the "sycophantic" nature of patronage, Woodhouse's actual relationship with his patrons, and his representation of this relationship within his poetry, indicate otherwise. No more sycophantic than submissive, Woodhouse's praise of his patrons encompasses an unexpectedly vocal capacity for both social criticism and moral prescription-insisting on benevolence, and gratitude, as redeeming communitarian acts. 95

\section{兔}

Tho' Memory, false, may furl up all the facts, Which constitute such fair, but fickle, pactsTho' every verbal document's deniedBy Passion blurr'd, or blotted out by PrideTho' heaps of prompt epistolary store Such mimic Friendship recollects no more; Yet will their inky characters remain, Among Mankind, a still-enduring stain.

(Crispinus Scriblerus, chap. 14, lines 1095-1102)

If Crispinus Scriblerus serves as a crucial literary record of late-century proto-proletarian perspectives, Woodhouse's epistolary correspondence from the years 1764 to 1767 sheds new light on the complex but connected social politics of patronage and publication for laboring-class poets throughout the eighteenth century. As I have argued, Woodhouse cultivated a genuinely close, coterie-like community with the patrons who assisted his poetic development while also confronting the class prejudices that threatened his equal participation in social, cultural, and literary spheres. A staunch defender of the "equality of Mankind," Woodhouse in his letters evinces an early form of evangelically inspired democratic thought antecedent to the sea change in popular politics stimulated by the French Revolution and Thomas Paine's The Rights of Man (1791), which saturated the period in which he wrote his autobiography. 96 Instead of "two Woodhouses," therefore, which in Christmas's framing suggests a rigid

95. Woodhouse presents a challenge to the claim that mid- to late-century laboring-class verse lacked "a communitarian idiom (such as one based on universal rights and liberties that defined the 1790s)." Such an idiom appears to be in formation, at least, in the 1760 s. Aruna Krishnamurthy, introduction to The Working-Class Intellectual in Eighteenth- and Nineteenth-Century Britain (Farnham, U.K., 2009), 1-24 at 7.

96. Ian Haywood, The Revolution in Popular Literature: Print, Politics and the People, 1790-1860 (Cambridge, 2004), 21. 
schism between his early and later poetry, we would do better to think about the "published" and "unpublished" Woodhouses, reflecting the parallel-public and private, respectable and radical-lives that he combined throughout his long poetic career.

What the letters I have selected uncover, however, is that Woodhouse was not only expressing his political views in parallel with his early published poetry, but also within it. Whether in pseudonymous letters to periodicals, familiar letters to his patrons, or poems composed for publication, Woodhouse skillfully negotiated literary convention while at the same time pursuing a moralized critique of the forms of inequality persisting in British society. Although Woodhouse had much to thank his patrons for, his gratitude was accompanied by a conscious, even conspicuous, opposition to the servile and mercenary views of a sycophant. The early Woodhouse was respected by his patrons for his "honest freedom" and by reviewers for his "consciousness of that equality of nature which petitioners and dedicators too often prostitute or forget." His portrayal as a "sycophant" seems largely the construction of critics either oversensitive to the conventional forms of address in this period or misapprehending the marked ability of laboring-class poets to simultaneously occupy and oppose dominant and dominating cultural discourses. Bringing to light his powerful but privately expressed egalitarianism, this exploration of Woodhouse's letters pursues a recuperation similar to that which resulted from the publication of Robert Bloomfield's collected correspondence in 2009.97 This edition demonstrated, as John Goodridge writes, that the much-maligned Bloomfield "was capable of resisting the overawing power of patronly beneficence, albeit with strain and difficulty." ${ }^{8}$ No less markedly, the public and private letters of James Woodhouse allow us to appreciate the degree to which deference and defiance could go hand in hand in laboring-class writing.

I am grateful for the support and assistance of the Huntington Library in producing this essay, especially Sara K. Austin and Susan Green; special thanks are also due to William Christmas, Steve Van-Hagen, and Abigail Williams for their generous comments and advice, and to the audiences of the British Society for Eighteenth-Century Studies and Linacre College, Oxford, where early versions of this paper were presented.

ADAM J. BRIDGEN is a doctoral student of English at Linacre College, University of Oxford. His research explores the significance of transatlantic slavery in British laboring-class poetry in the long eighteenth century. Before commencing his $\mathrm{PhD}$, he worked as an assistant researcher for the Digital Miscellanies Index.

97. Robert Bloomfield (1766-1823), another shoemaker-turned-poet, made his name with the hugely successful georgic The Farmer's Boy (1800). Bloomfield in fact met Woodhouse in 1802. Robert Bloomfield to George Bloomfield, August 16, 1802, in The Letters of Robert Bloomfield and His Circle, ed. Tim Fulford and Lynda Pratt, on the Romantic Circles website, last modified September 2009, www.rc.umd.edu/editions/bloomfield_letters.

98. Goodridge, "Labouring-Class Poetry," 17. 